\title{
Benthic macroinvertebrates as bioindicators of environmental quality of Pará River estuary, a wetland of Eastern Amazon
}

\author{
Macroinvertebrados bentônicos como bioindicadores da qualidade ambiental do estuário do Rio Pará, uma área \\ úmida da Amazônia Oriental \\ Álvaro José de Almeida Pinto ${ }^{1}$ (D) Vanessa Bandeira da Costa Tavares ${ }^{2}$ (D), Samara Cristina Campelo Pinheiro ${ }^{2}$ (D), \\ Marcelo de Oliveira Lima² (D), Daiane Aviz ${ }^{3}$ (D), Aline Maria Meiguins de Lima ${ }^{4}$ (D)
}

\section{A B S T R A C T}

The study characterized and evaluated the use of the benthic macroinvertebrate community as an indicator of impacts in different estuarine environments around the Industrial Port Complex (IPC) of Vila do Conde (Pará State, Amazon region). Fauna of beaches and rivers, in sectors of the estuary under different degrees of environmental impact (high, medium, and (ow), was compared in different seasonal periods. Macrofauna was composed of typically fresh-water and estuarine groups. Beaches presented sediment with a texture ranging from medium to coarse sand, with a less rich macrofauna ( $\bar{X}=4.5 \pm$ SE 0.3 taxa/sample) and dense $(\bar{X}=1,838.1 \pm$ $\left.164.8 \mathrm{ind} . / \mathrm{m}^{2}\right)$ of organisms when compared to rivers $(\overline{\mathcal{X}}=5.9 \pm 0.3$ taxa/ sample, and $3,248.9 \pm 77.0$ ind. $\left./ \mathrm{m}^{2}\right)$, which were environments more muddy. For both environments, sites in the high-impact sector were less rich $(\bar{X}=4.7$ \pm 0.3 taxa/sample) and dense $\left(\bar{X}=2,812.9 \pm 232.7 \mathrm{ind} . / \mathrm{m}^{2}\right)$ when compared to those in the low-impact sector $(\bar{X}=7.6 \pm 0.4$ taxa/sample, and $3,314.3$ \pm 230.1 ind. $\left./ \mathrm{m}^{2}\right)$. Richness $(\bar{\chi}=6.4 \pm 0.3$ taxa/sample $)$ and density $(\bar{\chi}=$ $3,859.4 \pm 190.2$ ind. $\left./ \mathrm{m}^{2}\right)$ were higher in the rainier season when compared to the less rainy season $(\bar{X}=4.8 \pm 0.3$ taxa/sample, and 1,933.0 \pm 172.1 ind./ $\mathrm{m}^{2}$ ). However, there were no significant seasonal changes in composition. Results indicated that the structure of the benthic macroinvertebrate community surrounding the IPC responds to the loss of environmental quality, with extreme effects of a drop in abundance and diversity. Taxa that are more tolerant (Namalycastis caetensis, Cirolana sp., Pseudosphaeroma sp., Tubificidae, and Chironominae) and sensitive (Hydropsychidae and Eteone sp.) to impact conditions were identified and evaluated as potential bioindicators.

Keywords: macrofauna, environmental impact; industrial pole; Amazonian estuary.

\section{RE S U M 0}

O estudo caracterizou e avaliou o uso da comunidade de macroinvertebrados bentônicos como indicadora de impactos em diferentes ambientes estuarinos na área do Complexo Portuário Industrial (CPI) de Vila do Conde (Pará, região amazônica). A fauna de praias e rios, em setores do estuário sob diferentes graus de impacto ambiental (alto, médio e baixo), foi comparada em distintos períodos sazonais. A macrofauna foi composta por grupos tipicamente dulcícolas e estuarinos. As praias apresentaram sedimento com textura variando de areia média a grossa, com macrofauna menos rica ( $\bar{X}=4,5 \pm$ SE 0,3 táxons/amostra) e densa $\left(\bar{X}=1.838,1 \pm 164,8\right.$ ind. $\left./ \mathrm{m}^{2}\right)$, quando comparados aos rios $(\bar{X}=5,9 \pm$ 0,3 táxons/amostra e $3.248,9 \pm 77,0$ ind. $\left./ \mathrm{m}^{2}\right)$, os quais foram ambientes mais lamosos. Para ambos os ambientes, locais no setor de alto impacto eram de menor riqueza $(\bar{X}=4,7 \pm 0,3$ táxons/amostra) e densidade $(\bar{X}=2.812,9 \pm$ 232,7 ind./ $\left./ \mathrm{m}^{2}\right)$, quando comparados ao do setor de baixo impacto $(\bar{X}=7,6 \pm$ 0,4 táxons/amostra e $3 \cdot 314,3 \pm 230,1$ ind./ $\mathrm{m}^{2}$ ). A riqueza $(\bar{X}=6,4 \pm 0,3$ táxons/ amostra) e densidade $\left(\bar{X}=3.859,4 \pm 190,2\right.$ ind. $\left./ \mathrm{m}^{2}\right)$ foram mais altas no período mais chuvoso, do que no período menos chuvoso $(\bar{X}=4,8 \pm 0,3$ táxons/amostra e $1.933,0 \pm 172,1$ ind. $\left./ \mathrm{m}^{2}\right)$. Contudo, não ocorreram modificações sazonais significativas na composição. Os resultados indicaram que a estrutura da comunidade de macroinvertebrados bentônicos no entorno do CPI responde à perda da qualidade ambiental, com efeitos extremos de queda na abundância e diversidade. Táxons mais tolerantes (Namalycastis caetensis, Cirolana sp., Pseudosphaeroma sp., Tubificidae e Chironominae) e sensíveis (Hydropsychidae e Eteone sp.) às condições de impactos foram identificados e avaliados como potenciais bioindicadores.

Palavras-chave: macrofauna, impacto ambiental; polo industrial; estuário amazônico.

${ }^{1}$ Professor, Universidade da Amazônia - Belém (PA), Brazil.

${ }^{2}$ Researcher in Public Health, Instituto Evandro Chagas - Belém (PA), Brazil.

${ }^{3}$ Researcher, Museu Paraense Emílio Goeldi - Belém (PA), Brazil.

${ }^{4}$ Professor, Universidade Federal do Pará - Belém (PA), Brazil.

Correspondence address: Álvaro José de Almeida Pinto - Avenida Alcindo Cacela, 287 - Umarizal - CEP: 66060-000 - Belém (PA), Brazil -

E-mail: alvarojosealmeidap@gmail.com

Conflicts of interest: the authors declare that there are no conflicts of interest.

Funding: Public Ministry of the State of Pará (MPE-PA), through the Conduct Adjustment Term (TAC) with cooperation from the Evandro Chagas Institute (IEC).

Received on: 04/14/2020.Accepted on: 07/09/2020.

https://doi.org/10.5327/Z2176-947820200760 


\section{Introduction}

Roughly 30\% of the Amazon's territory is protected by humid areas, which are highlighted for providing environmental services that guarantee the maintenance of biodiversity and the sustenance of human communities (BARROS; ALBERNAZ, 2014; CARVALHO; PIMENTEL; LIMA, 2019). These areas form the basis of aquatic food chains, for they have a high primary and secondary production, as well as a great diversity of plant and animal species, including invertebrates and vertebrates, many of which are valuable fishing resources (JUNK et al., 2011). Besides that, they are essential for recharging aquifers, containing floods and soil erosion, retaining nutrients, and contaminants (CAVALCANTE et al., 2015).

The use of environmental indicators which assess and provide data for quality management and conservation of environments is recommended for ecosystems with a high degree of sensitivity, such as those found in humid areas (JUNQUEIRA et al., 2018; CHANAMÉ-ZAPATA et al., 2019; MEHROTRA; BARDHAN; RAMAMRITHAM, 2019). An organism, or assembly of organisms, is considered a bioindicator when it presents a response that can be identified in the face of differences (natural variations), or changes (anthropic impacts) in its surroundings. (LIJTEROFF; LIMA; PRIERI, 2009).

Benthic macroinvertebrates are animals that have an average size of $0.5 \mathrm{~mm}$ and live all or part of their lives inside or on the bottom of aquatic environments (CAMARGO, 2019). They are one of the most recommended groups in literature for diagnosis and environmental monitoring, due to some attributes, such as:

- presence in practically all aquatic systems, favoring comparative studies;

- sedentary nature and relatively short life cycle, which allows a more effective spatial and temporal analysis of the effects of impacts;

- and a large number of species present therein, offering a wide range of responses to environmental stress;

- the numerous methods in the community studied, which have been used at the level of community monitoring and individual responses (FERREIRA; PAIVA; CALLISTO, 2011; JUNQUEIRA et al., 2018).

The Industrial Port Complex (IPC) of Vila do Conde, in Barcarena City, Pará State, is one of the largest industrial centers in the Amazon region. The complex was created in 1976 and has, in addition to the port area, several mineral processing outsourced companies, associated with the mineral sector and general trade (QUEIROZ et al., 2019). As a result of these activities, the region had its economy modified, which caused an intense and disordered population growth (BORDALO; SILVA; SANTOS, 2012; HAZEU; COSTA; NASCIMENTO, 2019). Given this scenario, recurring accidents and environmental crimes were recorded in the region, which includes: leakage/spillage of petroleum-based fuels; spillage of ores and live cargo; overflows of waste from mineral tailings dams, and releases of urban and mineral effluents (IEC, 2018; FAIAL et al., 2009; FERREIRA, BELTRÃO, 2016; LIMA et al., 2018; PINHEIRO et al., 2019).

Effects of environmental impacts on aquatic biota at the Vila do Conde Industrial Pole were evaluated by some studies addressing plankton (phyto- and zooplankton) and ichthyofauna. Regarding plankton, changes in density of organisms, and a higher frequency of impacting species were observed in the areas closest to the port system (SENA et al., 2015; COSTA et al., 2016a; 2016b; PINHEIRO et al., 2019). In the ichthyofauna, in places close to the IPC, there was a reduction in the diversity of species and food guilds (VIANA; FRÉDOU; FRÉDOU, 2012; VIANA; FRÉDOU, 2014), in addition to a higher incidence of individuals with histopathological damage (VIANA et al., 2013). So far, only quick inventories have been carried out on the benthic community of the area,, with a view to environmental authorizations for the implantation of port and industrial enterprises.

Given the environmental vulnerability of aquatic resources in the area, the present study aims to characterize the community of benthic macroinvertebrates in different aquatic environments and seasonal periods, assessing possible changes in their structure, as well as their use as bioindicators of environmental quality.

\section{Materials and Methods}

Study site

The industrial complex of Vila do Conde has an area of 1,316.299 $\mathrm{km}^{2}$ and is located on the right bank of the Pará River estuary (CDP, 2010), in Pará State, on the Brazilian Amazon coast. The region's drainage network is formed by rivers of small orders and by the river Pará, a water body of great spatial extensions, with $30-40 \mathrm{~km}$ of distance between its banks, and $300 \mathrm{~km}$ of longitudinal extension, until its mouth in the Atlantic Ocean (PRESTES et al., 2017). The study site (Figure 1) is an estuarine region with a greater influence of fresh water, classified as a tidal freshwater estuary (ELLIOTT; MCLUSKY, 2002). On the banks of the river Pará, sand strips exposed during low tides are called beaches.

\section{Sampling network}

Quarterly collections were carried out from February to November 2012, covering two samples in the rainy period (February and May) and two in the less rainy period (August and November). A total of 10 collection stations were established (Figure 1) to cover the main drainages surrounding the industrial complex. Six of the stations were located on small rivers' stretches under the influence of tides: the river Arrozal (ARZ), the river Murucupi (MUR), the river São Francisco (SF), the river Curuperê-Dende (DEN), the river Arienga (ARI), the river Arapiranga (ARA); and four on the beaches of the river Pará: Caripi Beach (CAR), Itupanema Beach (ITU), Conde Beach (CON), and Beja Beach (BEJ).

The collection stations were distributed in three sectors with different potential impacts, according to secondary data on water quality, land use, and history of environmental impacts in the area. The sectors were: 
- high impact sector (DEN, MUR, CON, and ITU), in the IPC area, including the port of Vila do Conde, in addition to large companies in the mineral sector, such as Hydro Alunorte and Imerys Rio Capim; the presence of sewage discharges and industrial effluents (BRABO et al., 2003; LIMA et al., 2009);

- medium impact sector (ARZ, SF, CAR), downstream from the IPC, with urban occupation and close to areas of companies in the mineral sector, with events for the discharge of solid materials, and of domestic and industrial effluents (FAIAL et al., 2009; LIMA et al., 2009);
- low impact sector (ARA, ARI and BEJ) upstream of the IPC, with riparian forests relatively preserved compared to other drainages nearby; and good water quality (LIMA et al., 2009; COSTA et al., 2016a; 2016b).

Field activities and laboratory

Two collection points (about $100 \mathrm{~m}$ apart) were established for rivers to distribute the sampling along the impacted stretch. On beaches, only one collection point was established. At each point, three biological samples were taken with the aid of a Van Veen dredge

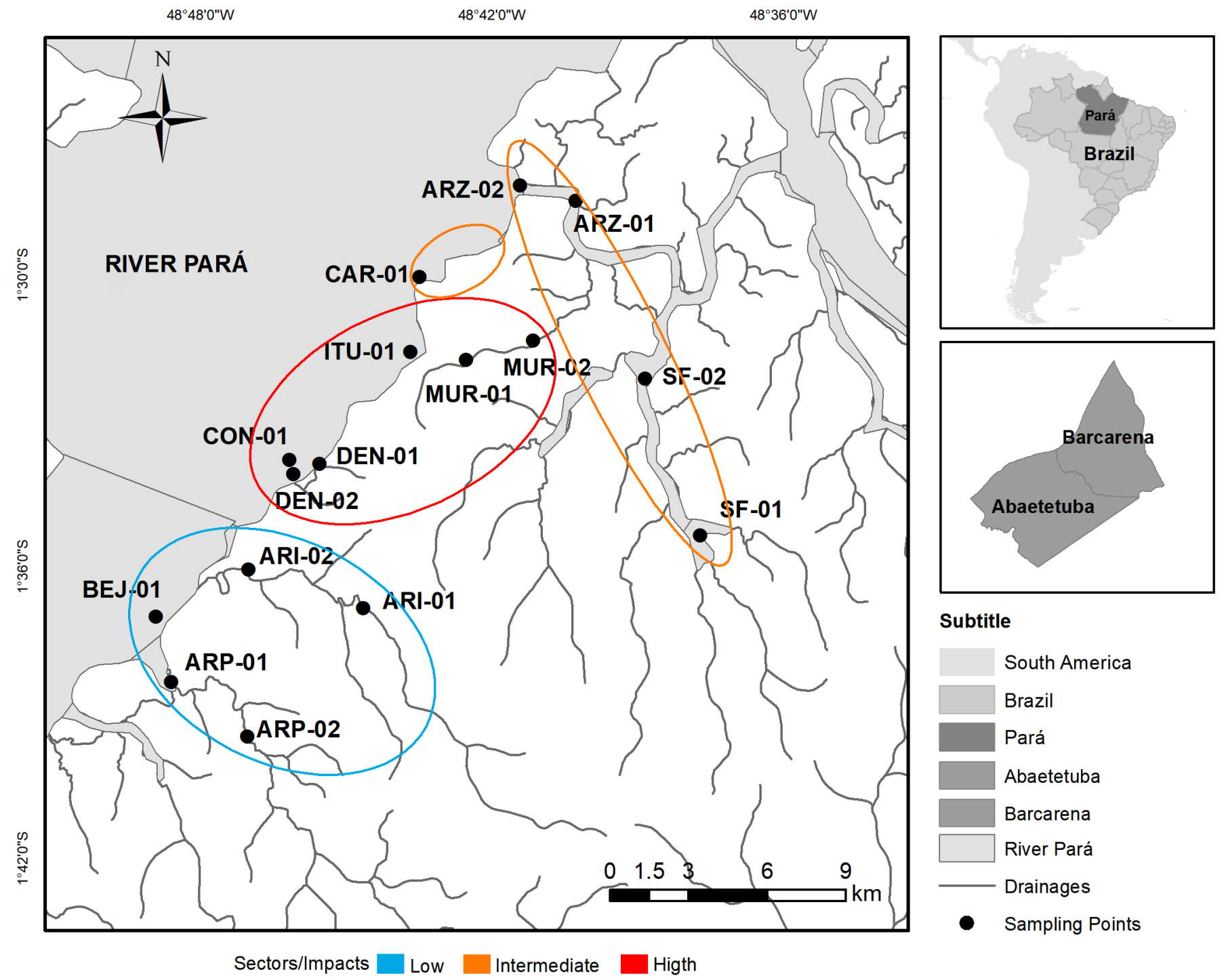

Figure 1 - Sampling network for benthic macroinvertebrates around the Industrial Port Complex of Vila do Conde (Barcarena City, Pará State, Brazil). Rivers: Arrozal (ARZ), Murucupi (MUR), São Francisco (SF), Curuperê-Dende (DEN), Arienga (ARI), Arapiranga (ARP); Estuarine beaches on the river Pará: Itupanema (ITU); Conde (CON), and Beja (BEJ). 
$(20 \times 20 \times 20 \mathrm{~cm})$, at a depth of about $2 \mathrm{~m}$. On each occasion and location, a sediment sample was collected for granulometric and total organic matter analysis. Biological samples were passed with a 0.3 $\mathrm{mm}$ opening mesh; retained material was preserved in a $5 \%$ formaldehyde solution. Sample for abiotic analysis was cooled in the field and frozen in laboratory.

In the laboratory, biological samples were screened, and organisms counted, identified at the lowest possible taxonomic level, and preserved in $70 \%$ ethyl alcohol. For sediment samples, granulometry was determined by sieving the coarse and pipetting the fines (SUGUIO, 1973). Organic matter content was determined by the muffle calcination method at $550^{\circ} \mathrm{C}$ for four hours (adapted from Davies, 1974). Statistical parameters (mean grain diameter, textural classification, and proportions of sand, silt, and clay) of the sediment were calculated using the equations proposed by Folk and Ward (1957).

\section{Data analysis}

Regarding sediment data, a principal component analysis (PCA) was applied to identify similarity and the most important variables for grouping locations, environments, and climatic periods. For analysis, data were first standardized and normalized; the Euclidean Distance was used to calculate similarity.

For each biological sample, biological descriptors were calculated: total abundance (number of individuals), average density (individuals per $\mathrm{m}^{-2}$ ), richness (by simply counting the number of taxa), and diversity (Shannon-Winner index). To verify spatial variations of these descriptors, the three-way ANOVA was applied for the following treatments: climatic period (less rainy and rainy), environment (river and beach), and seasons (nested to the environmental factor). ANOVA was followed by Tukey's test whenever null hypothesis was rejected. Before ANOVA, normality of data distribution (Kolmogorov-Smirinov test), and homoscedasticity of variances (Levene's test) were tested, and, when needed, transformed.

For comparison of the structure of communities in different treatments, permutational multivariate analysis of variance (PERMANOVA) was applied (ANDERSON, 2005), following the same model applied in ANOVA. Grouping analysis (CLUSTER) was used to identify spatial patterns, according to the average distance method. For both analyzes, a similarity matrix constructed from Bray Curtis similarity index was used, calculated based on data on density. Similarity Percentage (SIMPER) routine was applied to identify the most important taxa for group similarity. Finally, indicator species index (IndVal) (DUFRÊNE; LEGENDRE, 1997) was applied to associate the taxa with types of environment and impact sectors. IndVal ranges from 0 to $100 \%$, in which zero is equivalent to the non-indication of species for a given environmental status, and 100 indicates that the occurrence of a given species is characteristic of that environment. In conjunction with IndVal, the Monte Carlo test (with 1,000 randomizations) was performed to confirm the indication value significance. For all analyzes, a significance level of 5\% was used.

\section{Results}

\section{Precipitation}

In general, rainfall rates for Barcarena City during the study period showed clear seasonal patterns and followed the climatological normal of the last 30 years (Figure 2). However, in the rainy season, rates much higher than those expected were recorded in March, June, and July 2012. For the less rainy period, September and October 2012, total precipitation was above and below the expected, respectively.

\section{Sediment parameters}

The sediment parameters of collection sites are shown in Table 1. Comparatively, beaches presented essentially sandy sediment, whereas rivers were predominantly muddy. For rivers, sediment ranged from fine silt (the rivers Murucupi, Curuperê-Dende, and Arienga) to medium silt (the rivers Arrozal, São Francisco, and Arapiranga), with organic matter above $5 \%$. In both periods, the highest organic contents were observed in the rivers Arienga, Curuperê-Dende, and Murucupi. The presence of leaflets was observed predominantly in sediment samples from rivers (Table 1).

On beaches (Beja and Caripi) of relatively less impacted sectors, sediment was classified as medium sand, in both periods, and organic percentage varied from 3.5 to $5.1 \%$ (Table 1). In the sectors with the greatest impact (Itupanema and Conde), classification was of coarse (rainy season) and medium (less rainy) sand, always with a larger average grain size compared to the other beaches. Organic percentage on beaches under high impact ranged from 3.4 to $4.6 \%$ (Table 1). PCA analysis classified the environments as river and beach, according to their textural characteristics. However, concerning the periods, identifying seasonal patterns was not possible (Figure 3).

\section{Benthic macroinvertebrates \\ General composition}

A total of 2,024 organisms was collected, classified into 30 different taxonomic units (Supplementary material). The phylum Annelida was the most abundant, representing $54.8 \%$ of the total organisms collected, followed by Arthropoda (35.1\%), Nematoda (7.3\%), Mollusca $(2.5 \%)$, and Platyhelminthes (0.4\%). In general, Polychaeta, Oligochaeta, and Insecta were the most abundant groups in rivers. Nonetheless, some distinctions were observed in-between seasons (Figure 4). In the high-impact sector, the river Curuperê-Dende was dominated by Nematoda, followed by Oligochaeta. On the river Mucurupi, highlights were Insecta and Oligochaeta. In the intermediate impact sector, polychaete worms (Rice) and insects (São Francisco) were the most representative. In the low impact sector, although polychaetes and oli- 
gochaetes were also dominant, there was greater participation of crustaceans and mollusks (Figure 4).

On beaches, polychaete worms dominated in Beja and Caripi, low and medium impact sectors, respectively; whereas crustaceans and oligochaetes were the most representative groups in Conde and Itupanema (Figure 4). Mollusks were not very representative and presented greater abundance in the river Arienga and the beaches Beja and Caripi.

\section{Descriptors of benthic assemblies}

ANOVA indicated significant variation in density, richness, and diversity, considering the different environments, collection seasons, and seasonal periods (Table 2). In general, macrobenthic assemblages of rivers were significantly denser and more diverse (number of taxa and diversity index) than those of beaches (Figure 5), although these descriptors showed low values in some rivers. In-between seasonal periods, significant variations were identified for density and total richness, without interaction with other factors. In general, the highest values of density and richness were recorded in the rainy season.

Regarding rivers, the macrofauna observed in the river Arrozal (intermediate impact sector) had the highest average density, with values significantly different from all other locations, except for the river Arapiranga in the rainy season (Figure 5). On the other hand, in the rivers São Francisco, Curuperê-Dendê, and Murucupi, the macrofauna was of lower density. For beaches' macrofauna, Caripi and Beja were significantly denser than Itupanema and Conde during the rainy season. In the less rainy season, assemblies on Itupanema and Conde were significantly more abundant than those on Beja.

As to richness and diversity, a similar pattern of abundance was observed; however, the highest values of the indices were observed in the rivers Arapiranga and Arienga (low impact sector), which, as well as Arrozal, differed significantly from the rivers São Francisco, Curuperê-Dendê, and Murucupi (Figure 5). In turn, among beaches, Beja and Caripi were richer than Conde and Itupanema in the rainy season. In the less rainy season, only Beja was richer than Conde beach.

\section{Spatio-temporal variability of the macroinvertebrate community structure}

PERMANOVA indicated that the structure of macrobenthic associations is dissimilar when comparing rivers and beaches, just as there are differences between locations within each type of environment (Table 3). There were no significant changes in-between seasonal periods. All rivers had a significantly dissimilar fauna structure, except for

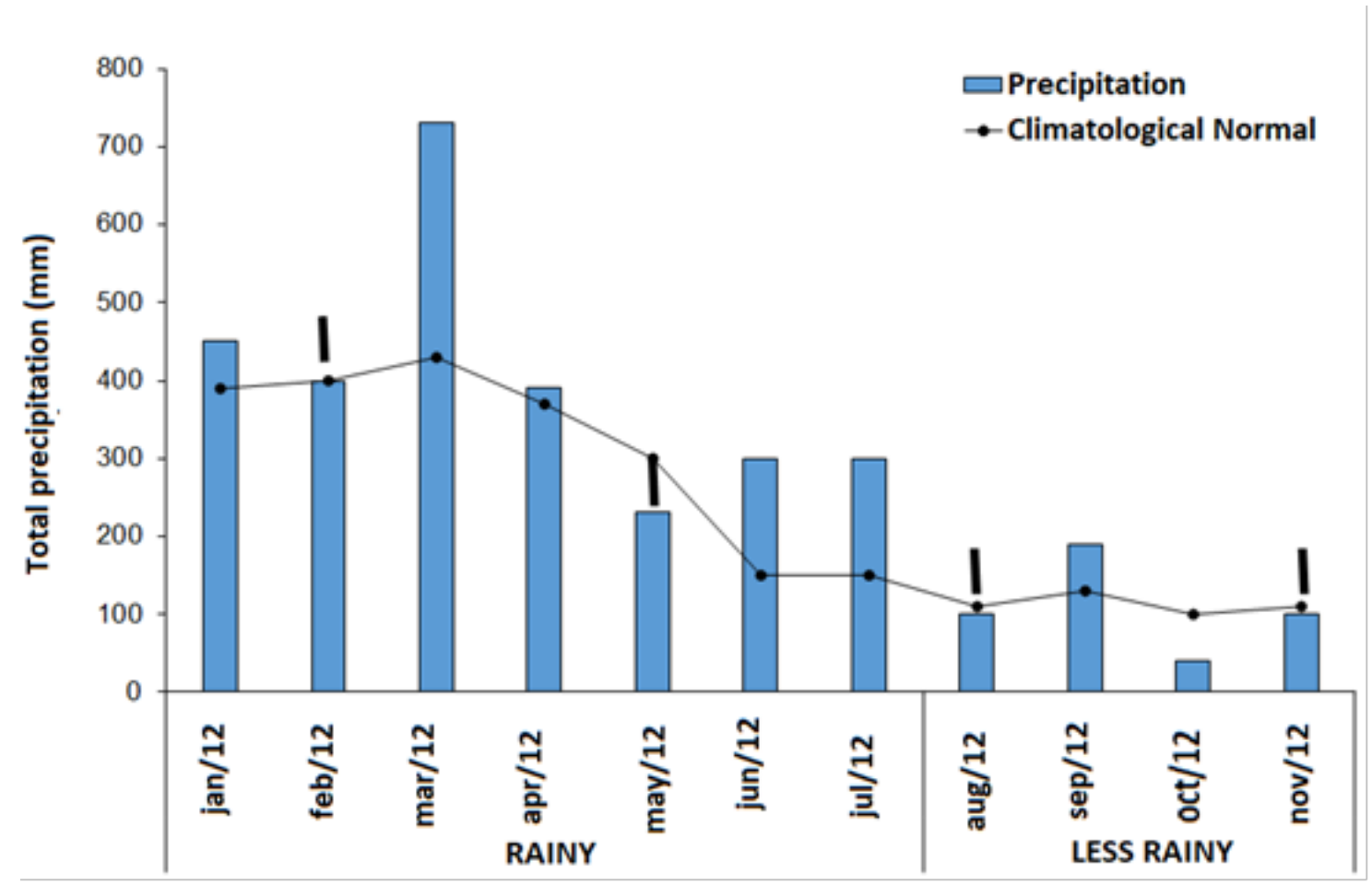

Figure 2 - Total monthly precipitation (bars) for the study period, and normal climatology (lines) for the last 30 years (1989-2019). The arrows indicate collection months.

Source: Based on data from INMET (2012). 
Table 1 - Sediment characteristics in collection stations. Rivers: Arrozal (ARZ), Murucupi (MUR), São Francisco (SF), Curuperê-Dende (DEN), Arienga (ARI), and Arapiranga (ARA). Beaches: Caripi (CAR), Itupanema (ITU), Conde (CON), and Beja (BEJ).

\begin{tabular}{|c|c|c|c|c|c|c|c|c|c|c|}
\hline \multirow{2}{*}{ Parameter/Period } & \multicolumn{6}{|c|}{ RIVERS } & \multicolumn{4}{|c|}{ BEACHES } \\
\hline & ARA & ARI & ARZ & SF & DEN & MUR & BEJ & CAR & ITU & $\mathrm{CON}$ \\
\hline \multicolumn{11}{|l|}{ Rainy period } \\
\hline Gravel (\%) & $4.2 \pm 0.1$ & $3.9 \pm 0.2$ & $3.6 \pm 0.1$ & $1.4 \pm 0.3$ & $4.1 \pm 0.2$ & $0.6 \pm 0.2$ & $4.5 \pm 0.1$ & $1.4 \pm 0.2$ & $2.4 \pm 0.1$ & $3.6 \pm 0.2$ \\
\hline Sand (\%) & $18.4 \pm 0.4$ & $23.1 \pm 0.2$ & $20.1 \pm 0.1$ & $10.2 \pm 0.3$ & $8.8 \pm 0.1$ & $24.3 \pm 0.1$ & $81.3 \pm 0.1$ & $92.3 \pm 0.3$ & $63.4 \pm 0.4$ & $91.2 \pm 0.1$ \\
\hline Silt (\%) & $71.1 \pm 0.2$ & $66.2 \pm 0.3$ & $71.3 \pm 0.1$ & $81.3 \pm 0.2$ & $82.1 \pm 0.1$ & $68.9 \pm 0.1$ & $8.1 \pm 0.2$ & $3.6 \pm 0.3$ & $26.4 \pm 0.2$ & $4.2 \pm 0.1$ \\
\hline Clay (\%) & $6.3 \pm 0.3$ & $6.8 \pm 0.2$ & $5.0 \pm 0.3$ & $7.1 \pm 0.2$ & $5.0 \pm 0.1$ & $6.2 \pm 0.2$ & $6.1 \pm 0.2$ & $2.7 \pm 0.2$ & $7.8 \pm 0.1$ & $1.0 \pm 0.1$ \\
\hline MO (\%) & $6.3 \pm 0.5$ & $9.1 \pm 0.3$ & $6.1 \pm 0.3$ & $5.6 \pm 0.5$ & $8.4 \pm 0.3$ & $8.9 \pm 0.1$ & $5.1 \pm 0.3$ & $3.5 \pm 0.2$ & $4.1 \pm 0.2$ & $3.4 \pm 0.1$ \\
\hline Grain size $(\varnothing)$ & $5.4 \pm 0.3$ & $5.4 \pm 0.2$ & $5.2 \pm 0.1$ & $5.6 \pm 0.2$ & $6.2 \pm 0.1$ & $5.1 \pm 0.1$ & $2.4 \pm 0.2$ & $2.4 \pm 0.1$ & $2.1 \pm 0.2$ & $2.1 \pm 0.2$ \\
\hline Verbal classification & Silt M & Silt M & Silt M & Silt F & Silt F & Silt M & Sand M & Sand M & Sand C & Sand C \\
\hline Presence of leaflet & + & + & + & + & + & + & - & - & - & - \\
\hline \multicolumn{11}{|l|}{ Less rainy period } \\
\hline Gravel (\%) & $1.6 \pm 0.1$ & $2.8 \pm 0.1$ & $3.1 \pm 0.1$ & $3.8 \pm 0.1$ & $4.5 \pm 0.1$ & $0.5 \pm 0.1$ & $2.5 \pm 0.2$ & $0.8 \pm 0.1$ & $1.6 \pm 0.2$ & $2.9 \pm 0.1$ \\
\hline Sand (\%) & $10.8 \pm 0.2$ & $31.9 \pm 0.4$ & $20.2 \pm 0.5$ & $17.6 \pm 0.2$ & $18.9 \pm 0.3$ & $20.5 \pm 0.4$ & $84.0 \pm 0.3$ & $83.4 \pm 0.2$ & $90.8 \pm 0.2$ & $95.1 \pm 0.3$ \\
\hline Silt (\%) & $84.8 \pm 0.2$ & $57.5 \pm 0.1$ & $70.5 \pm 0.1$ & $75.3 \pm 0.1$ & $72.9 \pm 0.2$ & $69.0 \pm 0.5$ & $8.1 \pm 0.2$ & $10 \pm 0.2$ & $6.7 \pm 0.2$ & $2.4 \pm 0.3$ \\
\hline Clay (\%) & $2.8 \pm 0.1$ & $7.8 \pm 0.1$ & $4.4 \pm 0.1$ & $3.3 \pm 0.1$ & $3.8 \pm 0.1$ & $10.0 \pm 0.2$ & $5.4 \pm 0.1$ & $5.8 \pm 0.2$ & $0.9 \pm 0.1$ & $2.5 \pm 0.3$ \\
\hline MO (\%) & $5.3 \pm 0.3$ & $8.1 \pm 0.3$ & $9.1 \pm 0.6$ & $5.6 \pm 0.5$ & $8.4 \pm 0.2$ & $7.9 \pm 0.2$ & $3.9 \pm 0.1$ & $4.6 \pm 0.1$ & $4.00 \pm 0.1$ & $4.5 \pm 0.2$ \\
\hline Grain size $(\varnothing)$ & $5.4 \pm 0.3$ & $5.2 \pm 0.2$ & $5.3 \pm 0.1$ & $5.4 \pm 0.2$ & $5.5 \pm 0.1$ & $5.2 \pm 0.1$ & $1.0 \pm 0.2$ & $1.8 \pm 0.1$ & $2.0 \pm 0.1$ & $2.0 \pm 0.1$ \\
\hline Verbal classification & Silt M & Silt M & Silt M & Silt M & Silt M & Silt M & Sand M & Sand M & Sand M & Sand $M$ \\
\hline Presence of leaflet & + & + & + & + & + & + & + & - & - & - \\
\hline
\end{tabular}

MO= organic matter; Silt F = fine silt; Silt M= medium silt; Sand M= medium sand; Sand C = coarse sand; + = present leaflet; - = without leaflet

Curuperê-Dende and Mucurupi. As to beaches, Itupanema and Conde had a similar structure, whereas all the other comparisons resulted in significant dissimilarity.

PERMANOVA's results did not indicate significant seasonal variation in the structure of assemblies, or the interaction of this factor with spatial factors. Given that, ordination analyzes, SIMPER, and IndVal prioritized spatial patterns (comparisons between seasons/environments and impact sectors).

CLUSTER analysis (Figure 6) showed a separation of the samples of stations of low-impact sectors, considering rivers and beaches. These locations gather samples with greater density and species richness and presented as more common taxa, species of polychaetes (Namalycastis caetensis, Eteone sp. and Nephthys fluviatilis), as indicated by SIMPER (Table 4). Due to its composition and high abundance, the beach Beja exhibited a faunal structure similar to that of rivers. A group of locations (DEN, ITU, CON) of the high-impact sector was also observed. In the SIMPER analysis we noticed that the beaches in this group have Cirolana sp. as the most important taxon for sample similarity, and share with the Curuperê-Dende river the high frequency of Nematoda. The rivers Mucurupi and Arrozal form a group with more than $60 \%$ similarity, and SIMPER indicates $N$. caetensis, Chironominae, and Tubificidae as the most common. Caripi was also isolated from the other beaches, and its most frequent taxa were Eteone sp., N. fluviatilis, and Haplotaxidae.

IndVal values were low: only eight taxa had an indication value greater than $30 \%$ and significant (Table 5). Among these, the polychaetes N. caetensis and N. abiuma were indicatives of the rivers of the medium impact sector. For rivers of the low impact sector, only the larvae of Hydropsychidae were indicators. As to beaches, Eteone sp. was an indicator of low-impact beaches, Cirolana sp., Pseudosphaeroma sp. to the top, and N. fluviatilis for medium impact.

\section{Discussion}

\section{Composition and spatio-temporal variations}

Estuaries are environments of transition between fluvial and marine, characterized by the intense action of physical forcing, with emphasis on the entry of fresh water and tidal fluctuations (ELLIOTT; MCLUSKY, 2002). In tropical estuaries, spatial and temporal variability of salinity, which is influenced by rainfall and fluvial input, is the main macro factor to control biological processes. In Amazon's estuaries, under the influence of large rivers, such as the river Pará, penetration of saline waters from the Atlantic can be largely prevented, giving an 
oligohaline character (salinity between 0 and 5) throughout the entire estuary and the year (ROSA FILHO et al., 2018). Accordingly, in the river Parás stretch and the study period, surface water salinity ranged from 0.01 to 0.05 (ROSÁRIO et al., 2016; COSTA et al., 2016a; 2016b).

Concerning the bottom sediment, organic matter values of rivers and beaches in Pará river estuary, with percentages between 3.4 and 9.1\%, are higher than those registered in other Amazonian estuaries, with muddy or sandy sediments (SILVA et al., 2011; AVIZ; CARVALHO; ROSA FILHO, 2012; ROSA FILHO; AVIZ, 2013). This result may indicate enriched substrates in the surroundings of the IPC of Vila do Conde, considering that the release of untreated domestic organic effluents is one of the main contaminants of water in that area (COSTA et al., 2016a; 2016b).
The area's benthic macrofauna was composed of typically freshwater groups (such as insect larvae and oligochaete) (BATZER; BOIX, 2016) and estuarine (such as polychaetes, mollusks, and crustaceans) (ELLIOTT; MCLUSKY, 2002) with numerical dominance of few taxa. This combination is characteristic of estuaries dominated by rivers (SCHUCHARDT; HAESLOOP; SCHIRMER, 1993; ELLIOTT; MCLUSKY, 2002). In the Amazon, macrobenthic communities in estuarine areas are characterized by low taxonomic diversity and dominance of a small number of taxa, attributes that probably are reflections of the stress caused by macrotidal regimes and low salinity, permanent or imposed during some months of the year (ROSA FILHO et al., 2006; ROSA FILHO et al., 2018).

Values of density of organisms (with averages in the collection stations between 484.8 and 3,708 ind. $\mathrm{m}^{-2}$ ) and taxon richness (total

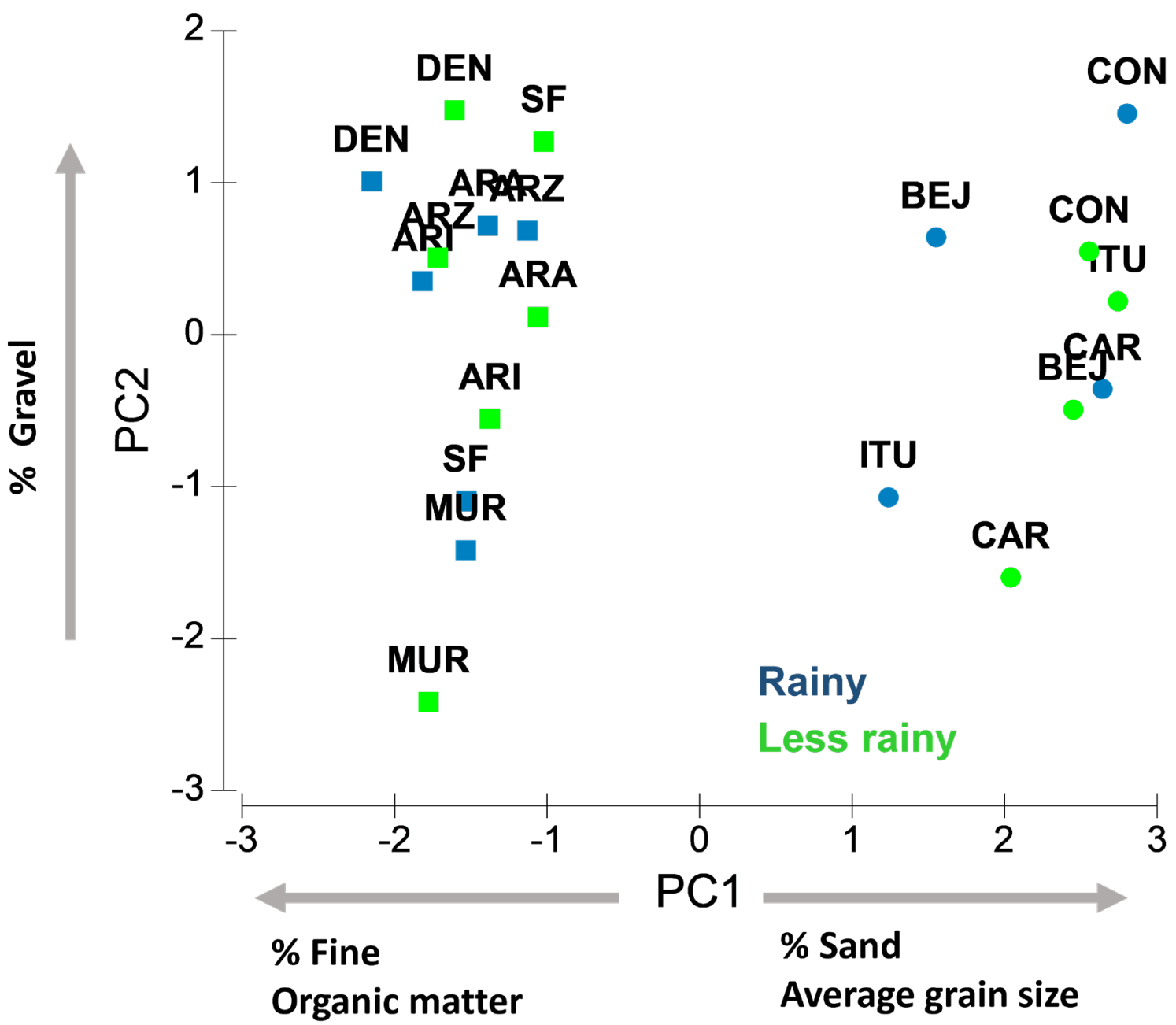

Figure 3 - Result of PCA analysis $(\mathrm{PC1}=62.8 \%, \mathrm{PC} 2=19.7 \%)$ for river sediment data (square) and beaches (circles) of Pará river estuary (Barcarena City, Eastern Amazon). Rivers: Arrozal (ARZ), Murucupi (MUR), São Francisco (SF), Curuperê-Dende (DEN), Arienga (ARI), and Arapiranga (ARA). Beaches: Caripi (CAR), Itupanema (ITU), Conde (CON), and Beja (BEJ).

OM: organic matter. 


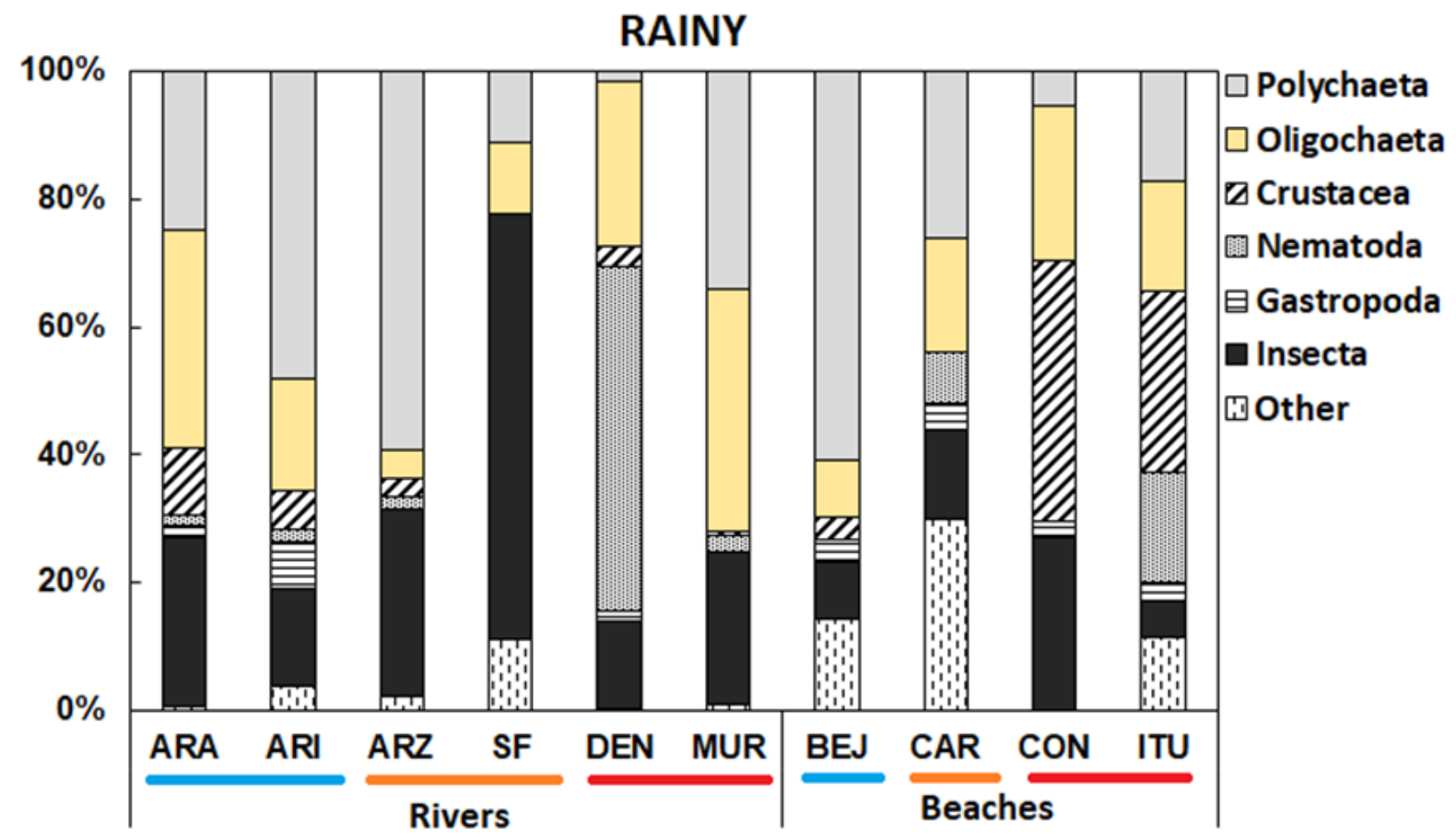

LESS RAINY

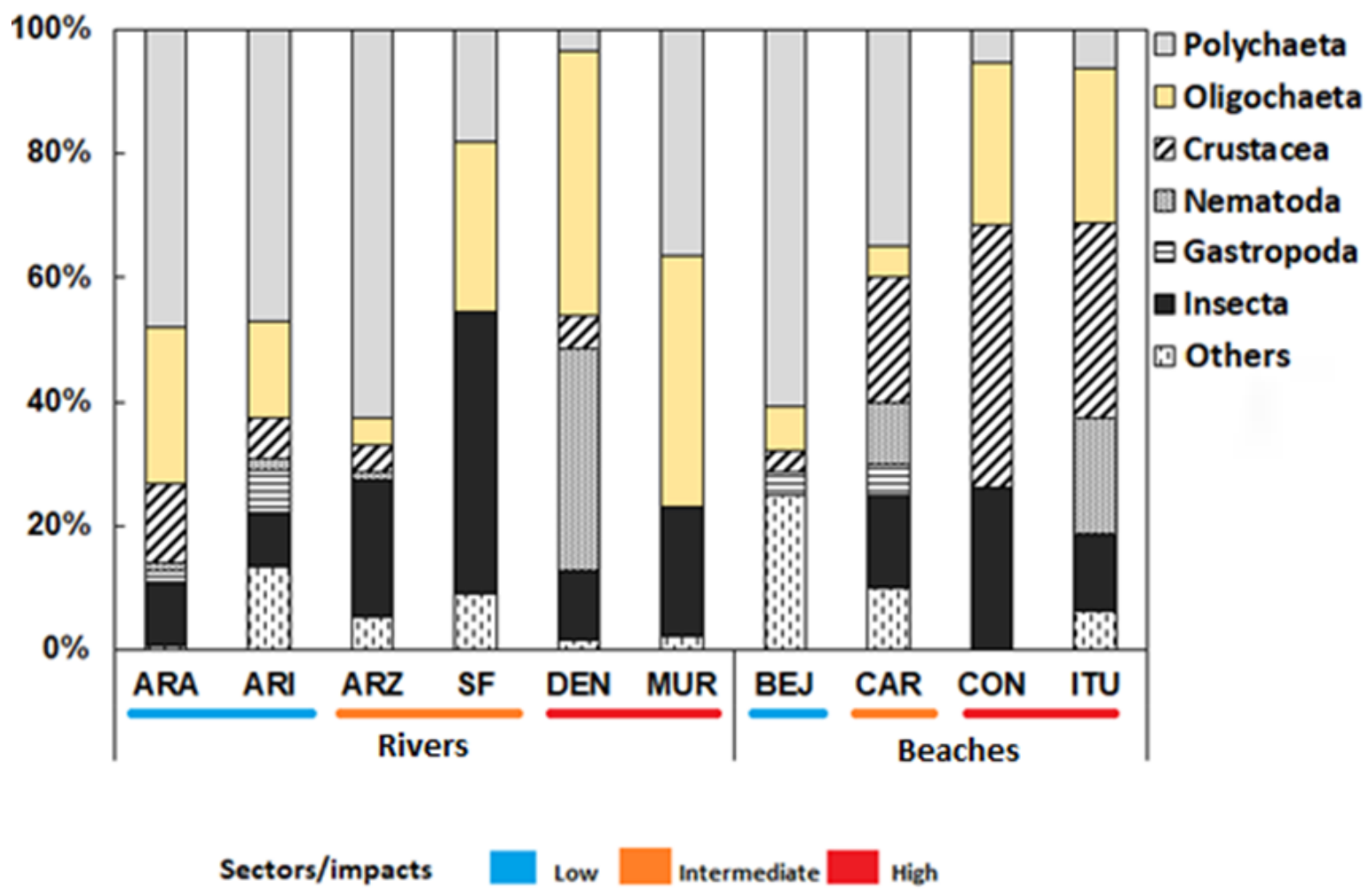

Figure 4 - Relative participation of taxonomic groups in the abundance of organisms in collection stations. Rivers: Arrozal (ARZ), Murucupi (MUR), São Francisco (SF), Curuperê-Dende (DEN), Arienga (ARI), Arapiranga (ARA). Estuarine beaches on the river Pará: Itupanema (ITU); Conde (CON), and Beja (BEJ). 
of 30 taxa) from Pará river estuary are consistent with those of other Amazonian estuaries. For example, in Guajará Estuary, with oligohaline waters $(<1)$, total richness was 22 taxa, and average density varied between 458.3 and 19,290.1 ind. $\mathrm{m}^{-2}$ (AVIZ; CARVALHO; ROSA FILHO, 2012). In the same estuary, Rosa Filho and Aviz (2013) recorded a richness of 39 taxa and densities between 403.1 and 5,181.2 ind. $\mathrm{m}^{-2}$. In the estuary of the river Caeté, in a stretch with salinity between 5.1 and 26.5 , the total number of taxons was 17 , and density varied from 664.6 to 14,399 ind. $\mathrm{m}^{-2}$ (ROSA FILHO et al., 2006).
The groups with the highest abundance in the area were Polychaeta, Oligochaeta, Nematoda worms, and Chironomidae larvae. Soft substrates (muddy and sandy-muddy) are especially conducive to wormlike domain, because they facilitate their movement and offer a greater amount of food, especially for deposit-eating species. In turn, Chironomidae larvae can be naturally abundant in continental environments, due to the high diversity of adult larvae in the terrestrial environment, in addition to the plasticity of habitat and tolerance of their larvae, which can use various food resources, including debris (FERRINGTON JR., 2008).

Table 2 - Results of the ANOVA analysis for the descriptors density, richness, and diversity, using the factors environment (river and beaches), collection stations, and seasonal periods.

\begin{tabular}{|c|c|c|c|c|c|c|c|}
\hline \multirow{2}{*}{ Variation source } & \multirow[b]{2}{*}{ gl. } & \multicolumn{2}{|c|}{ Density (ind.m²) } & \multicolumn{2}{|c|}{ Richness (No. taxa) } & \multicolumn{2}{|c|}{ Diversity (H') } \\
\hline & & $\mathbf{F}$ & p-value & $\mathbf{F}$ & p-value & $\mathbf{F}$ & p-value \\
\hline Environment (1) & 1 & 35.6 & $<0.01^{\star}$ & 11.3 & $<0.01^{\star}$ & 4.6 & $0.03^{*}$ \\
\hline Period (3) & 1 & 10.2 & $<0.01^{\star}$ & 20.3 & $<0.01^{\star}$ & 0.25 & 0.61 \\
\hline Interaction (1-3) & 1 & 0.3 & 0,54 & 0.04 & 0.83 & 0.00 & 0.99 \\
\hline
\end{tabular}
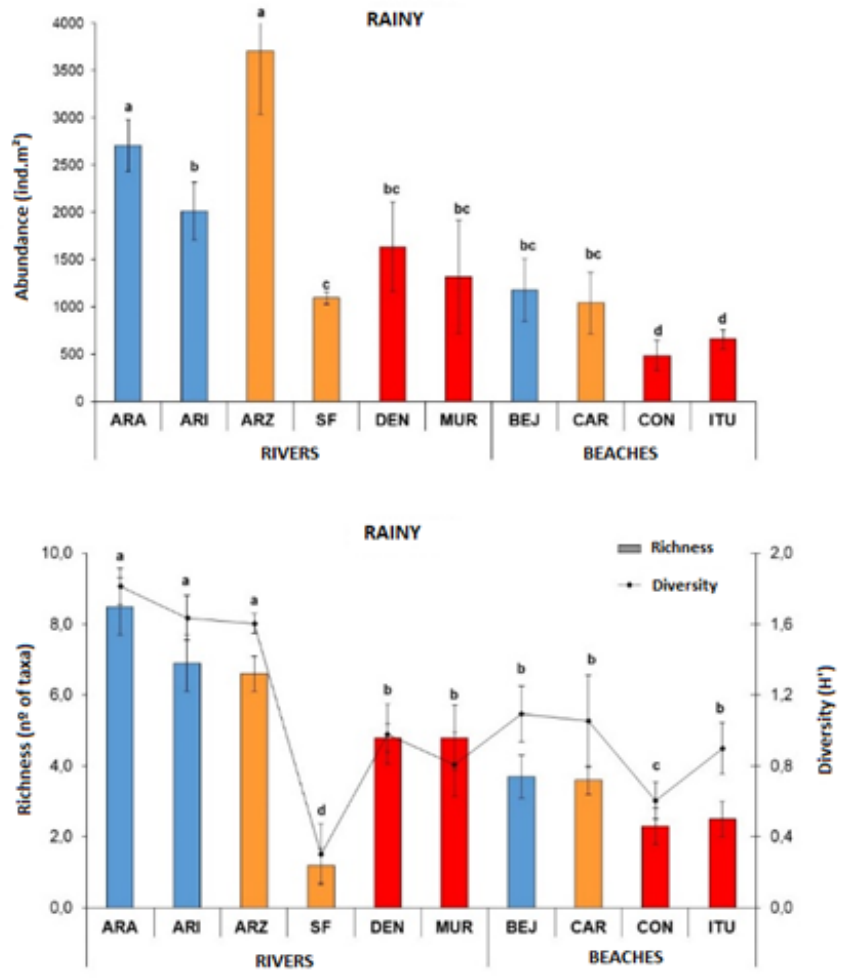
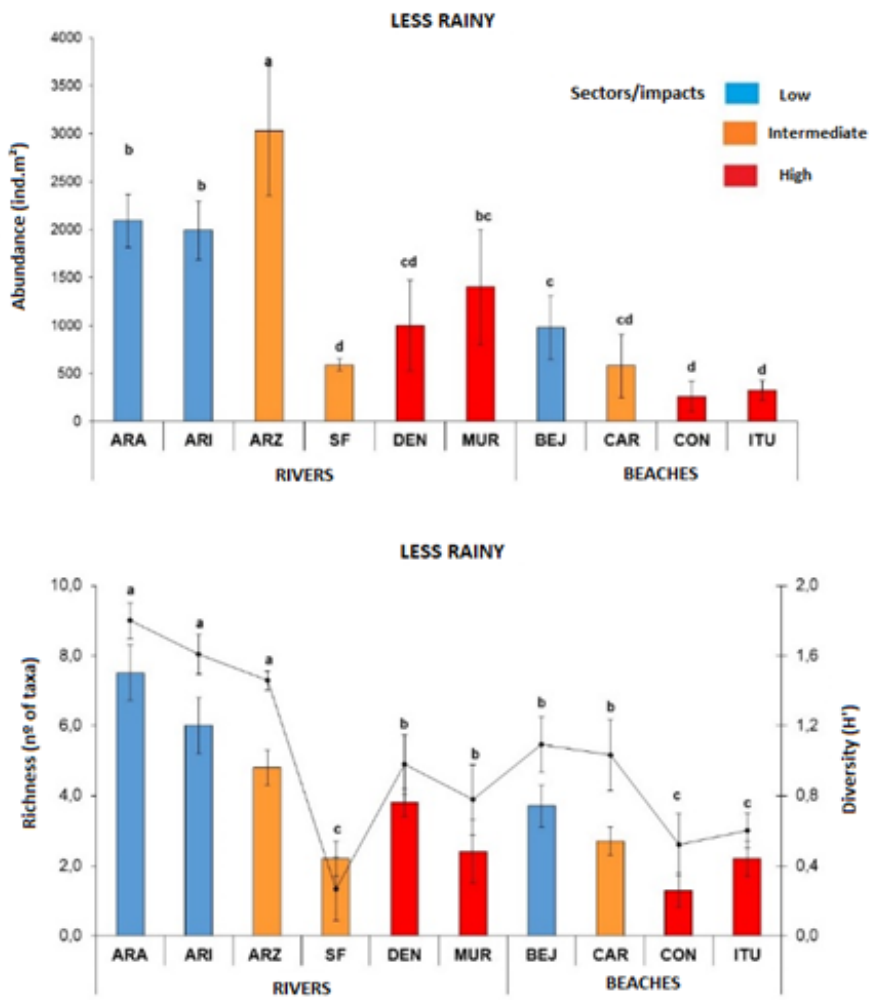

Figure 5 - Mean values ( \pm standard error) of density, richness, and diversity of macrobenthic assemblages during different seasonal periods (rainy and less rainy). Rivers: Arrozal (ARZ), Murucupi (MUR), São Francisco (SF), Curuperê-Dende (DEN), Arienga (ARI), and Arapiranga (ARA). Beaches: Caripi (CAR), Itupanema (ITU), Conde (CON), and Beja (BEJ). The letters above the averages represent the Tukey's test results; places that do not share letters differed significantly. 
In the river Pará, estuarine beaches were environments with a different composition, lower taxonomic richness, and a lower number of macrobenthic organisms when compared to small tributaries. Those beaches are environments subject to strong tidal currents, with less deposition of fine sediments, and a substrate composed of medium and coarse sands. In turn, small rivers presented more muddy sediment and submerged litter due to low hydrodynamic activity, the influence of soils, and adjacent vegetation. High substrate stability, the greater proportion of fine grains, and the greater supply of food and shelter are factors conducive to the development of benthic organisms (SWARTZ et al., 2019; BOSSLEY; SMILEY, 2019).

In beaches and rivers, the lowest values of richness and density were observed in high-impact sectors. In aquatic environments impacted by deforestation or the release of urban and industrial effluents, macrobenthic fauna tends to reduce density and taxonomic richness, due to the disappearance or decrease in the numbers of sensitive taxa (MACKINTOSH; DAVIS; THOMPSON, 2015).

In the beaches Conde and Itupanema, high-impact areas, the reduction in biological indexes was associated to more coarse and enriched sediments. In those beaches, the most abundant groups were isopods, tubificids, and chironomids. Tubificidae worms and Chironomidae larvae are known to tolerate habitat modifications, which include contamination by chemical and organic pollutants (PELLETIER et al., 2010; YOSHIDA; ROLLA, 2012; MACKINTOSH; DAVIS; THOMPSON, 2015). In turn, isopods are detritivore, opportunistic organisms, and many species are relevant and useful in environmental monitoring, due to their tolerance to chemical compounds and their great capacity to store metals (GHEMARI et al., 2019).

In addition to the intense urban occupation, the beaches of the river Pará are in an area of a greater influence of port facilities, which

Table 3 - PERMANOVA's results. Rivers: Arrozal (ARZ), Murucupi (MUR), São Francisco (SF), Curuperê-Dende (DEN), Arienga (ARI), and Arapiranga (ARA). Beaches: Caripi (CAR), Itupanema (ITU), Conde (CON), and Beja (BEJ).

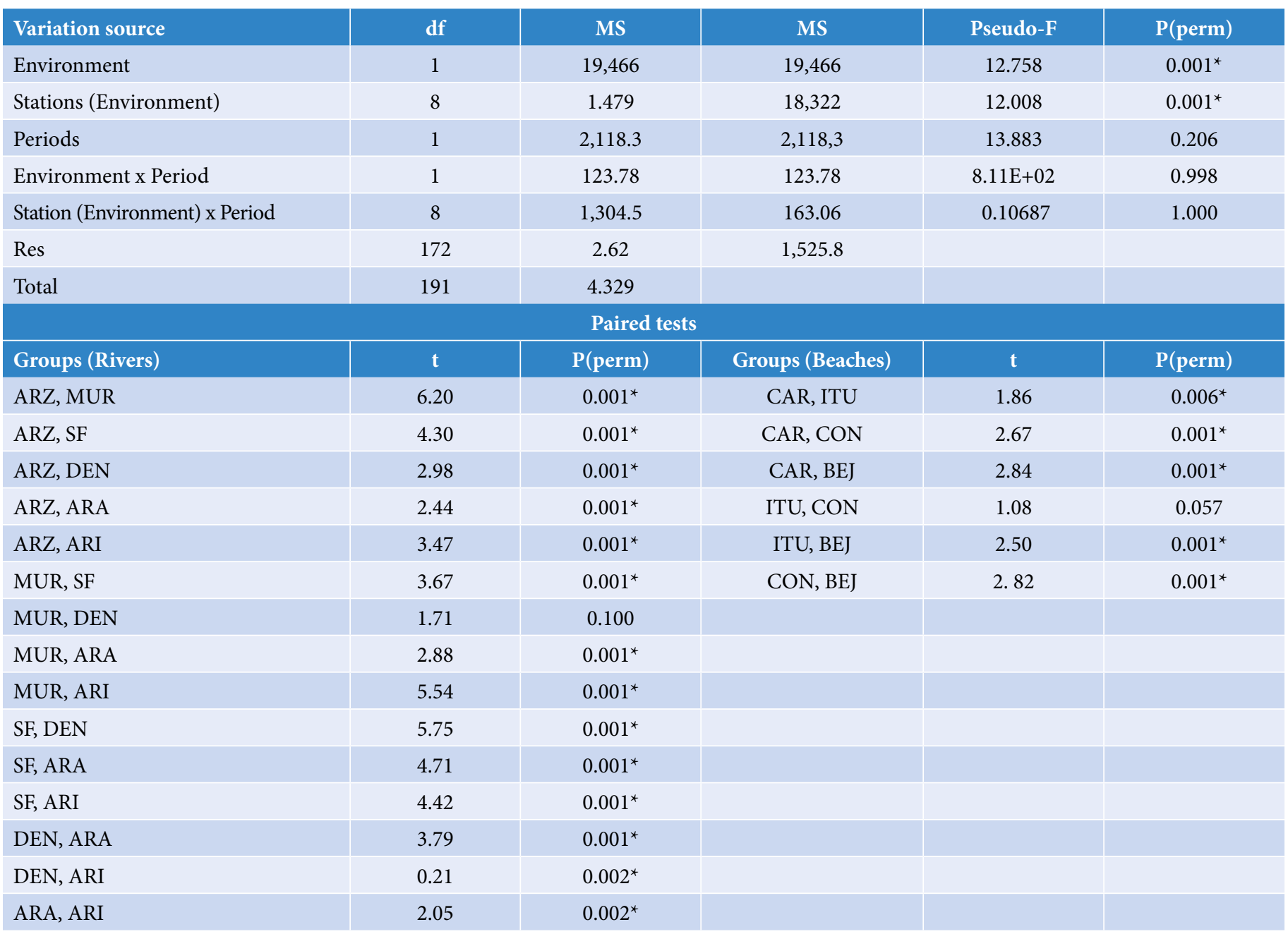


can affect the benthic community in different ways (MOSBAHI et al., 2019). Physical facilities, such as support and mooring structures, and pipelines, can alter local hydrodynamic patterns and sediment characteristics, which can include a decrease in local sedimentation (KAWASHIMA et al., 2016). Besides that, contamination of the environment can occur due to oil and fuel leaks from vessels or loss of materials (organic and inorganic) during loading and unloading these vessels (MOREIRA et al., 2019).

The high-magnitude river Arrozal, is in an area of intermediate impact, and presented the highest density of organisms, without a significant drop in the richness of taxa. The site is located downstream the industrial complex and, along its course, it receives discharges of urban effluents (mainly untreated domestic sewage). N. caetensis and tubificids, which are deposit consumers, were dominant in this river. Biostimulation can occur in areas with moderate organic enrichment (CULHANE et al., 2019) when organic supply is moderate, or sufficiently diluted; it does not compromise availability of oxygen for the biota, which contributes to increasing the abundance and the number of benthic species (ROSENBERG; RESH, 1993; AVIZ; CARVALHO; ROSA FILHO, 2012; KRUMHANSL et al., 2015; CULHANE et al., 2019).

Even though the river São Francisco is in an area of intermediate impact, it was the river with the least richness and abundance in the study site, in which Tubificidae, Chironominae, and N. caetensis were the dominant taxa. The stations on that river are the most internal to the continent, and the river drains a large continental area, including the urban area of Barcarena City. We believe that the lesser influence of the tides and less dilution of organic loads can contribute to less conducive conditions for the development of the estuarine fauna.

The main seasonal changes observed in macrobenthic assemblies were concerning the density of organisms and the number of species. The increase in the quantity of macrofauna in the rainy season may be associated to the increase in rainfall in the IPC area,

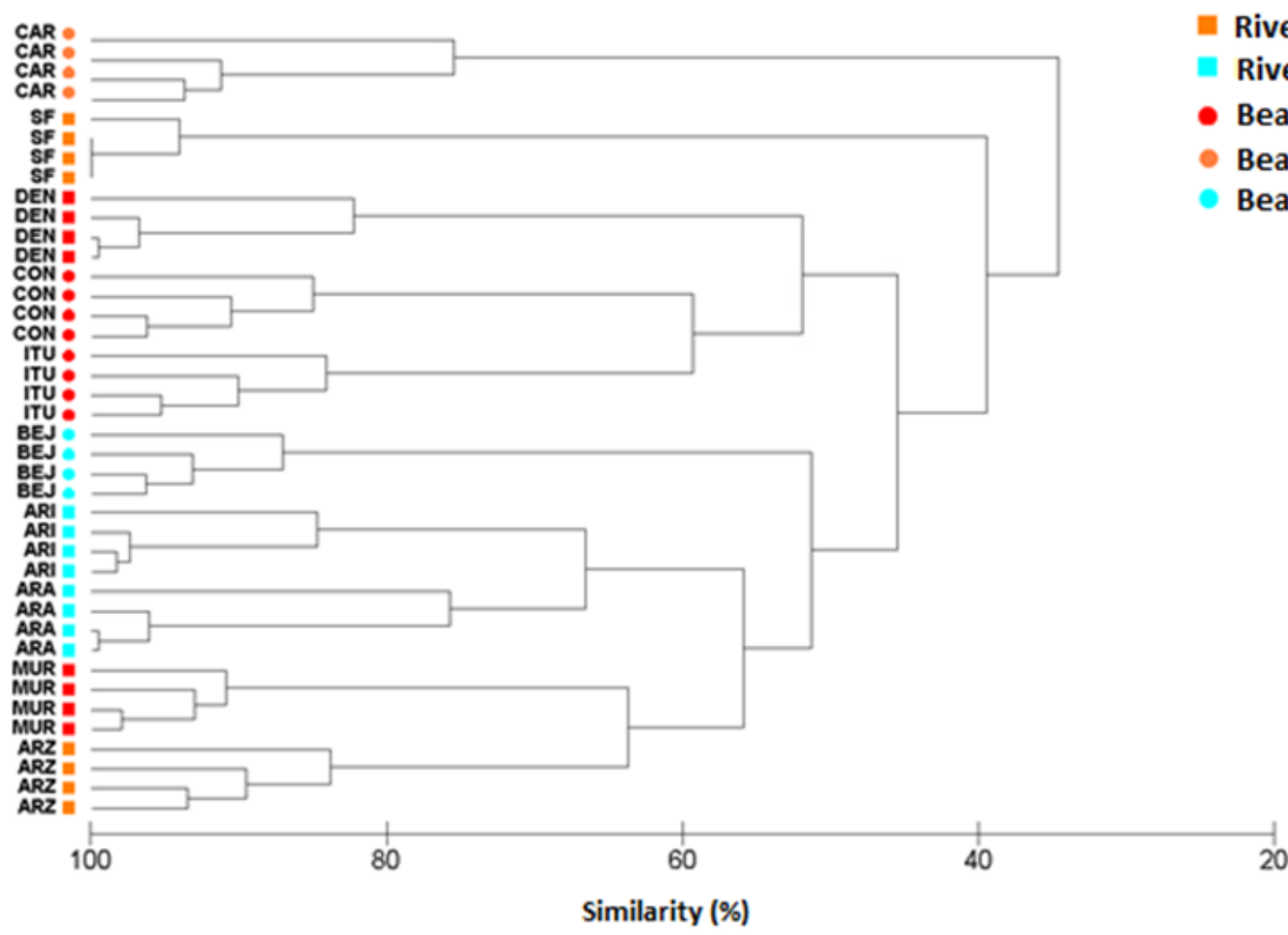

\section{Ambients/Impact sectors River/High \\ River/Intermediate River/Low \\ Beach/High \\ Beach/Intermediate Beach/Low}

Similarity (\%)

Figure 6 - Result of CLUSTER analysis for samples of benthic macroinvertebrates from Pará River estuary, in different environments and sectors of environmental impact. Rivers: Arrozal (ARZ), Murucupi (MUR), São Francisco (SF), Curuperê-Dendê (DEN), Arienga (ARI), and Arapiranga (ARA). Beaches: Caripi (CAR), Itupanema (ITU), Conde (CON), and Beja (BEJ). 
Table 4 - SIMPER results for similarity among the collection sites. Rivers: Arrozal (ARZ), Murucupi (MUR), São Francisco (SF), Curuperê-Dendê (DEN), Arienga (ARI), and Arapiranga (ARA). Beaches: Caripi (CAR), Itupanema (ITU), Conde (CON), and Beja (BEJ).

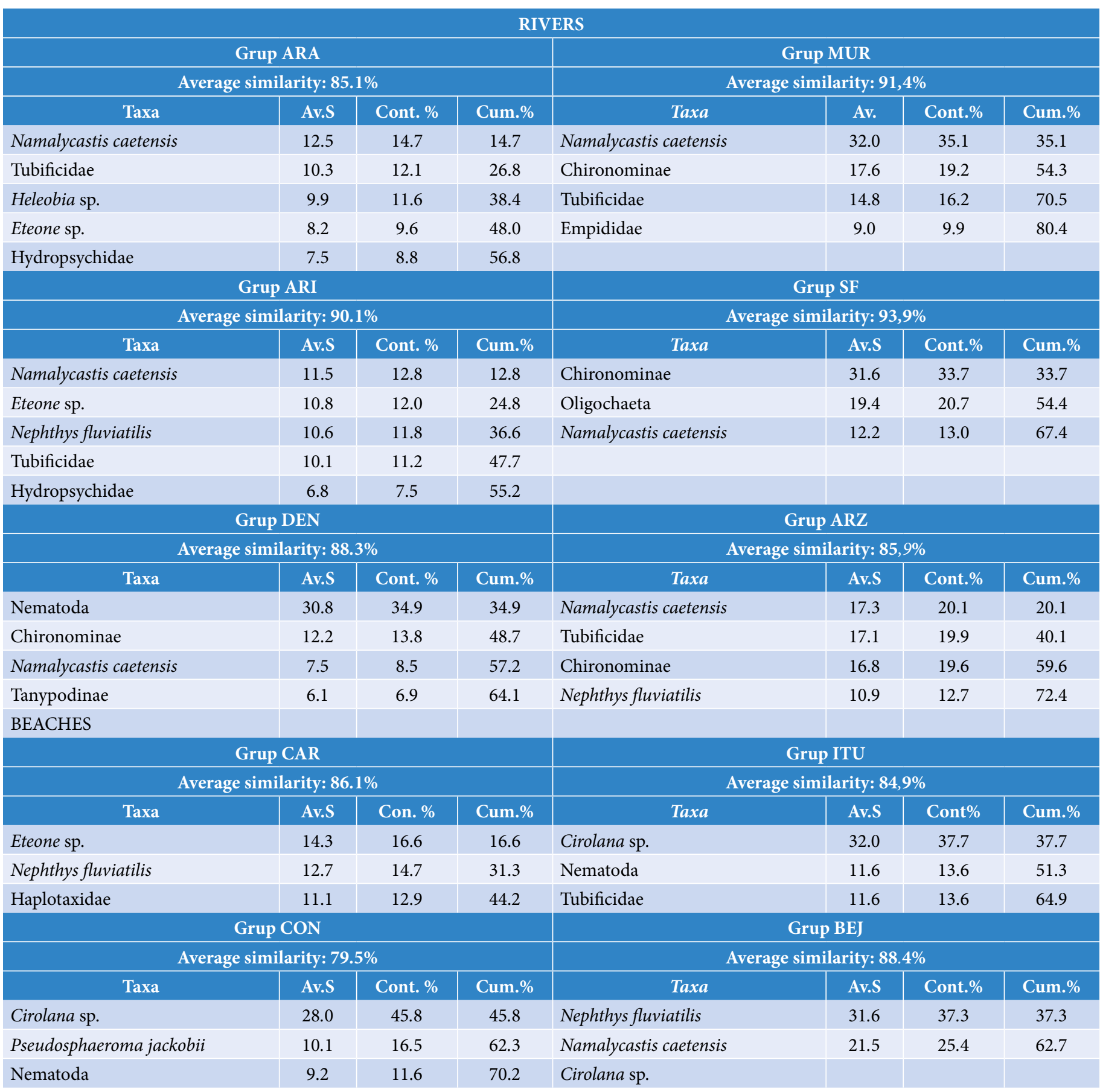

which significantly increases organic compounds in the water and can stimulate biota (COSTA et al., 2012a; 2012b). Although rains can naturally contribute to the transport of organic matter with leaching and flooding of forests, the continent's urbanization enhances the entry of nutrients into estuaries (KIMMERER, 2002).
Despite quantitative seasonal changes, the structure of assemblies, i.e., their composition, and the dominant groups were similar in-between the seasonal periods, as indicated by PERMANOVA. The permanent oligohaline condition of the estuary, even with the marked variation in rainfall, seems to keep the faunal structure differently from 
what occurs in the estuaries furthest from the mouth of the Amazon River, where salinity throughout the year can vary from 0 to 35 (ROSA FILHO et al., 2018). Additionally, the little seasonal variation in sediment texture can also contribute to greater stability in the benthic communities.

\section{Evaluation of species/bioindicator groups}

IndVal obtained a low indication value for most species, due to the low degree of specificity of these species with the impact conditions (high, medium, and low impact sectors). An indicator species must have high fidelity within the assessed ecological status, which is measured by its occurrence percentage (DUFRÊNE; LEGENDRE, 1997; MCGEOCH; RENSBURG; BOTES, 2002). According to McGeoch, Rensburg and Botes (2002), only species with IndVal values above $70 \%$ are characteristic or indicative of ecological status. Species with significant IndVal values, but less than $70 \%$, are considered detectors. Detector species are potential indicators of habitat change because they can change their preferred habitat more quickly than indicator species (VAN RENSBURG et al., 1999). Therefore, in the case of Pará River estuary, all taxa indicated by IndVal are detectors, and studies with longer time series are advised to confirm their use as bioindicators (MCGEOCH; RENSBURG; BOTES, 2002).

One of the most common estuarine organisms in the study site was Namalycastis caetensis, a species of polychaete recently described for Parás estuaries, in sandy-muddy areas of low salinity (ALVES; SANTOS, 2016). In Barcarena, N. caetensis was associated by IndVal to intermediate impact rivers, but it was present in practically all collection stations (low, medium, and high impact sectors), with higher densities in rivers with a muddy-sand substrate. The genus Namalycastis is generally found in places severely polluted by industrial effluents (rich in heavy metals) and is relatively resistant in toxicity tests that involve hydrocarbons and bioaccumulation of heavy metals (GLASBY, 1999; SARKAR, 2018).
The isopods Cirolanidae, Cirolana sp. and Pseudosphaeroma sp., were common on the beaches of the river Pará, more frequently in the high-impact sector. Generally, isopods are considered opportunistic taxa and tolerant to environmental impacts, which include metal pollution and organic enrichment (GHEMARI et al., 2019). In Brazil, other species of Cirolanidae, such as Excirolana brasiliensis, are considered good monitors of the environmental quality of marine beaches, due to their high resistance to environmental stress, persisting in highly urbanized areas (VELOSO; NEVES; CAPPER, 2011).

Nephtys fluviatilis was a frequent species in rivers and beaches, in a medium- and low-impact sector. IndVal showed a higher frequency of the species for beaches in medium-impact sectors. The polychaete $N$. fluviatilis is an active predator of the macro and meiofauna, and an occasional eater of deposits (SILVEIRA; ORTEGA; DUMONT, 2020), usually registered in Parás estuaries (ROSA FILHO et al., 2018; ROSA FILHO; AVIZ, 2013). The distribution of the species in the area reflects its preference for sandy-sandy substrates and the minor ability to colonize sandy substrates with thicker grains, such as impacted beaches.

Tubificidae oligochaetes were also a common component in rivers and beaches, with higher densities in rivers. This result is probably related to higher concentrations of fine grains, which commonly favor populations of those worms (RODRIGUEZ et al., 2001). Regarding environmental impacts, oligochaetes had greater participation in the abundance of rivers and beaches in sectors with the greatest impact. Tubificidae is known in literature as a tolerant and opportunistic species, with high densities recorded in places with habitat changes, such as eutrophic water and industrial pollution (ROSENBERG; RESH, 1993). Further efforts are recommended for specific taxonomic identification of the group, which still lacks specialists in the Amazon region.

When comparing polychaetes and oligochaetes, the first group of worms had greater participation in the abundance of rivers and beaches in sectors of greater impact. On the other hand, two other species of

Table 5 - Individual indication value (IndVal) for taxa of benthic macroinvertebrates from Pará River estuary in environments and sectors with different degrees of environmental impact.

\begin{tabular}{|l|c|c|c|}
\hline Taxa & Indicating valor & $\mathbf{p}^{*}$ & Environment (Impact sector) \\
\hline Namalycastis caetensis & 48.3 & 0.044 & River (medium impact) \\
\hline Cirolana sp. & 40.9 & 0.003 & Beach (high impact) \\
\hline Pseudosphaeroma sp. & 29.7 & 0.008 & Beach (high impact ) \\
\hline Hydropsychidae & 30.4 & 0.009 & River (low impact) \\
\hline Nephtys fluviatilis & 34.8 & 0.011 & Beach (medium impact) \\
\hline Namalycastis abiuma & 34.5 & 0.010 & River (medium impact) \\
\hline Eteone sp. & 35.1 & 0.003 & Beach (low impact ) \\
\hline Chironominae & 30.9 & 0.021 & River (high impact ) \\
\hline
\end{tabular}

${ }^{*}$ Monte Carlos test. 
polychaetes were associated to sectors of medium (Namalycastis abiu$m a$ ) and low impact (Eteone sp.). Similarly, Aviz, Carvalho e Rosa Filho (2012), in an Amazon's oligohaline estuary, recorded an increase in the participation of oligochaetes and a decrease in polychaetes in areas impacted by urban effluents.

Insect larvae were highlighted in the fauna structure of rivers and beaches, with different participation according to the order. Chironomidae larvae (Chironominae, Tanypodinae, and Ortocladiinae) were present in all collection stations, with emphasis on areas of high environmental impact. In turn, in the rivers Arapiranga and Arienga, the larvae of Trichoptera and other orders (Odonata, Coleoptera, etc.) were more frequent in more preserved hydrographic units.

Traditionally, Chironomidae is considered a tolerant group, and its dominance, when associated with low diversity and the absence, and/ or reduction of sensitive taxa, is a characteristic indication of environments with anthropic impacts (ARIMORO et al., 2018). The group's larvae are, in general, resistant to harsh conditions to other organisms, such as waters with high acidity, high temperatures, and low dissolved oxygen levels. (FERRINGTON JR., 2008; MOLINERI et al., 2019). In turn, Trichoptera larvae are considered indicators of good environmental quality, due to their sensitivity to impacts on water quality (HEPP et al., 2010; CHAGAS et al., 2017). Trichoptera larvae are usually more abundant in smaller rivers, with abundant vegetation and well-oxygenated waters (DE CAÍRES SOUZA; FERREIRA; MORAES, 2020), because they depend heavily on submerged leaf litter for protection, cocoon construction, and/or food. The result is that those organisms are extremely sensitive to soil use in watersheds (LECERF; RICHARDSON, 2010; COUCEIRO et al., 2012).
In addition to conditions of better chemical water quality (COSTA et al., 2016a; 2016b), the presence of organisms that are sensitive to impacts (e.g., the Trichoptera), as well as the greater taxonomic richness of the rivers Arapiranga and Arienga, is related to the degree of preservation of marginal vegetation. Forests are not only habitat for the adult forms of insects, but also provide stability to the soils and produce large amounts of leaf litter, which increases habitat heterogeneity (LECERF; RICHARDSON, 2010; SMETI et al., 2019).

\section{Conclusion}

Results indicate that the structure of the benthic macroinvertebrate community in the vicinity of the Industrial Port Complex of Vila do Conde responds to the loss of environmental quality, with events of decrease of abundance and taxonomic diversity. The groups found are typically deposit eaters, opportunistic, and adjusted to the oligohaline nature of the estuary. The low richness of the assemblies and the high dominance of few taxa are characteristics that should be considered in the area's environmental monitoring studies, as well as of another Amazon's estuaries, to differentiate the natural attributes of the macrobenthic assemblies from the effects arising from anthropic impacts. The polychaetae Namalycastis caetensis, Nephtys fluviatilis, Namalycastis abiuma, and Eteone sp., the crustaceans Cirolana sp. and Pseudosphaeroma sp., and the larvae of Hydropsychidae and Chironominae were identified as potential bioindicators. Nonetheless, in the view of their wide distribution in the area and low fidelity to the impact conditions, further studies with longer time series should be conducted.

\section{Contribution of authors:}

Pinto, A.J.A.: Conceptualization, Methodology, Validation, Formal analysis, Investigation, Data curation, Writing — original draft, Writing - review and editing. Tavares, V.B.C.: Supervision, Project administration. Pinheiro, S.C.C.: Supervision, Project administration. Lima, M.O.: Supervision, Project administration. Aviz, D.: Conceptualization, Methodology, Validation, Formal analysis, Investigation, Data curation, Writing — original draft, Writing — review and editing. Lima, A.M.M.: Writing - revision and editing.

\section{References}

ALVES, P.R.; SANTOS, C.S. Description of a new species of Namalycastis (Annelida: Nereididae: Namanereidinae) from the Brazilian coast with a phylogeny of the genus. Zootaxa, v. 4144, n. 4, p. 499, 2016. https://doi. org/10.11646/zootaxa.4144.4.3

ANDERSON, M.J. Permanova: A Fortran Computer Program for Permutational Multivariate Analysis of Variance. Auckland: Department of Statistics, University of Auckland, 2005.

ARIMORO, F.O.; AUTA, Y.I.; ODUME, O.N.; KEKE, U.N.; MOHAMMED, A.Z. Mouthpart deformities in Chironomidae (Diptera) as bioindicators of heavy metals pollution in Shiroro Lake, Niger State, Nigeria. Ecotoxicology and Environmental Safety, v. 149, p. 96-100, 2018. https://doi.org/10.1016/j. ecoenv.2017.10.074

AVIZ, D.; CARVALHO, I.L.R.; ROSA FILHO, J.S. Spatial and temporal changes in macrobenthic communities in the Amazon coastal zone (Guajará Estuary, Brazil) caused by discharge of urban effluents. Scientia Marina, v. 76, n. 2, p. 381-390, 2012. https://doi.org/10.3989/ scimar.03312.16C

BARROS, D.F.; ALBERNAZ, A.L.M. Possible impacts of climate change on wetlands and its biota in the Brazilian Amazon. Brazilian Journal of Biology, v. 74, n. 4, p. 810-820, 2014. https://doi.org/10.1590/1519-6984.04013 
BATZER, D.; BOIX, D. An introduction to freshwater wetlands and their invertebrates. In: BATZER, D.; BOIX, D. (eds.). Invertebrates in Freshwater Wetlands an International Perspective on their Ecology. New York: Springer, 2016. p. 1-24. https://doi.org/10.1007/978-3-319-24978-0_1

BORDALO, C.; SILVA, F.; SANTOS, V. Por uma gestão dos recursos hídricos no estado do Pará: Estudo de caso da bacia hidrográfica do Rio Murucupi no município de Barcarena. Revista Geonorte, v. 3, n. 4, p. 1216-1228, 2012.

BOSSLEY, J.P.; SMILEY, P.C. Impact of student-induced disturbance on stream macroinvertebrates differs among habitat types. Scientific Reports, v. 9, p. 1447, 2019. https://doi.org/10.1038/s41598-018-38210-1

BRABO, E.S.; FAIAL, K.R.F.; LIMA, M.O.; SANTOS, J.G.; MENDES, R.A. Relatório preliminar da avaliação da mortandade de peixes no rio Murucupi no município de Barcarena - estado do Pará. Ananindeua: Instituto Evandro Chagas, 2003.

CAMARGO, J.A. Positive responses of benthic macroinvertebrates to spatial and temporal reductions in water pollution downstream from a trout farm outlet. Knowledge \& Management of Aquatic Ecosystems, n. 420, p. 16-24, 2019 https://doi.org/10.1051/kmae/2019010

CARVALHO, S.; PIMENTEL, M.A.; LIMA, A.M.M. Desafios da área de proteção ambiental em território insular: proposição de planejamento para gestão de recursos hídricos sob a perspectiva dos moradores da ilha do Combu, Belém, Pará. Revista Brasileira de Ciências Ambientais, n. 51, p. 62-78, 2019. https://doi.org/10.5327/Z2176-947820190446

CAVALCANTE, H.L.; LOPES, A.; PIEDADE, L.; LIBERATO, R.M.A.R.; FERREIRA, C.S. Como funcionam as árvores das florestas inundáveis da Amazônia? In: LOPES, E.; PIEDADE, M.T.F. (eds.). Conhecendo as áreas úmidas amazônicas: uma viagem pelas várzeas e igapós. Manaus: INPA, 2015. p. 117-128.

CHAGAS, F.B.; RUTKOSKI, C.F.; BIENIEK, G.B.; VARGAS, G.D.L.P.; HARTMANN, P.A; HARTMANN, M.T. Utilização da estrutura de comunidades de macroinvertebrados bentônicos como indicador de qualidade da água em rios no sul do Brasil. Ambiente \& Água, v. 12, n. 3, p. 416-425, 2017. https://doi.org/10.4136/ambi-agua.2015

CHANAMÉ-ZAPATA, F.C.; CUSTODIO-VILLANUEVA, M.; YARANGACANO, R.M.; PANTOJA-ESQUIVEL, R.A. Diversity of the riparian vegetation of high Andean wetlands of the Junín region, Peru. Ambiente \& Água, v. 14, n. 3, p. 1-15, 2019. https://doi.org/10.4136/ambi-agua.2271

COMPANHIA DOCAS DO PARÁ (CDP). Relatório técnico 003: Atualização do plano de desenvolvimento e zoneamento do Porto de Vila do Conde, situado no Município de Barcarena, Belém/Pará. Belém: Companhia Docas do Pará, 2010.

COSTA, B.N.S.; PINHEIRO, S.C.C.; AMADO, L.L.; OLIVEIRA LIMA, M. Microzooplankton as a bioindicator of environmental degradation in the Amazon. Ecological Indicators, v. 61, part 2, p. 526-545, 2016a. https://doi. org/10.1016/j.ecolind.2015.10.005

COSTA, B.N.S.; PINHEIRO, S.C.C.; LIMA, M.O.; AMADO, L.L. Microzooplankton as an indicator of environmental quality at an industrial complex in the Brazilian Amazon. Ecological Indicators, v. 66, p. 220-229, 2016b. https://doi.org/10.1016/j.ecolind.2016.01.033

COUCEIRO, S.R.M.; HAMADA, N.; FORSBERG, B.R.; PIMENTEL, T;P.; LUZ, S.L.B. A macroinvertebrate multimetric index to evaluate the biological condition of streams in the Central Amazon region of Brazil. Ecological Indicator, v. 18, p. 118-125, 2012. http://dx.doi.org/10.1016/j. ecolind.2011.11.001

CULHANE, F.; BRIERS, R.; TETT, P.; FERNANDES, T. Response of a marine benthic invertebrate community and biotic indices to organic enrichment from sewage disposal. Journal of the Marine Biological Association of the United Kingdom, v. 99, n. 8, p. 1721-1734, 2019. http://dx.doi.org/10.1017/ S0025315419000857

DAVIES, B.E. Loss-on-ignition as an estimate of soil organic matter 1. Soil Science Society of America Journal, v. 38, n. 1, p. 150-151, 1974. http://dx.doi. org/10.2136/sssaj1974.03615995003800010046x

DE CAÍRES SOUZA, J.L.; FERREIRA, V.M.B.; MORAES, M. Survey of aquatic insects on a stretch of Tijuca River, Floresta da Tijuca-Rio de Janeiro, Brazil. Research, Society and Development, v. 9, n. 1, e148911847, 2020. http://dx.doi. org/10.33448/rsd-v9i1.1847

DUFRÊNE, M.; LEGENDRE, P. Species assemblages and indicator species: the need for flexible asymmetrical approach. Ecological Monographs, v. 67, n. 3, p. 345366, 1997. https://doi.org/10.1890/0012-9615(1997)067[0345:SAAIST]2.0.CO;2

ELLIOTT, M.; MCLUSKY, D.S. The need for definitions in understanding estuaries. Estuarine, Coastal and Shelf Science, v. 55, n. 6, p. 815-827, 2002. https://doi.org/10.1006/ecss.2002.1031

FAIAL, K.C.F.; FAIAL, K.R.F.; LIMA, M.O.; CARNEIRO, B.S.; MENDES, R.A.; MEDEIROS, A.C.; DEUS, R.J.A.; JESUS, I.M.; SANTOS, E.C.O.; FERNANDES, K. G. Avaliação da Contaminação do Sedimento por Rejeitos de Lama Vermelha no rio Murucupi, Barcarena-PA, Brasil. Revista Brasileira de Toxicologia, v. 22, suppl. 1, p. 11, 2009.

FERREIRA, F.N.; BELTRÃO, N.E.S. A importância da valoração na ação civil pública ambiental: um estudo de caso do naufrágio em rio amazônico. Contribuciones a las Ciencias Sociales, p. 1-15, 2016.

FERREIRA, W.R.; PAIVA, L.T.; CALLISTO, M. Development of a benthic multimetric index for biomonitoring of a neotropical watershed. Brazilian Journal of Biology, v. 71, n. 1, p. 15-25, 2011. https://doi.org/10.1590/S151969842011000100005

FERRINGTON JR., L.C. Global diversity of non-biting midges (Chironomidae; Insecta-Diptera) in freshwater. Hydrobiologia, v. 595, p. 447455, 2008. https://doi.org/10.1007/s10750-007-9130-1

FOLK, R.L.; WARD, W.C. Brazos River bar [Texas]: a study in the significance of grain size parameters. Journal of Sedimentary Research, v. 27, n. 1, p. 3-26, 1957. https://doi.org/10.1306/74D70646-2B21-11D7-8648000102C1865D

GHEMARI, C.; WATERLOT, C.; AYARI, A.; DOUAY, F.; NASRI-AMMAR, K. Effects of Heavy Metals Artificial Contamination on Porcellio laevis (Latreille, 1804) (Crustacea: Isopoda: Oniscidea). Bulletin of Environmental Contamination and Toxicology, v. 103, n. 3, p. 416-420, 2019. https://doi. org/10.1007/s00128-019-02684-0

GLASBY, C.J. The Namanereidinae (Polychaeta: Nereididae), Part 1. Records of the Australian Museum, v. 25, suppl. 25, p. 1-129, 1999.

HAZEU, M.T.; COSTA, S.M.G.; NASCIMENTO, N.S.F. Comunidades tradicionais e sindicatos em conflito com estado e capital em Barcarena (PA). Argumentum, v. 11, n. 1, p. 173-187, 2019. http://10.18315/argumentum. v11i1.22671

HEPP, L.U.; MILESI, S.V.; BIASI, C.; RESTELLO, R.M. Effects of agricultural and urban impacts on macroinvertebrates assemblages in streams (Rio Grande do Sul, Brazil). Zoologia, v. 27, n. 1, p. 106, 2010. https://doi.org/10.1590/ S1984-46702010000100016

INSTITUTO EVANDRO CHAGAS (IEC). Avaliação Preliminar dos Impactos Ambientais Referente do Transbordo e Lançamentos Irregulares de Efluentes de Lama Vermelha da Cidade de Barcarena, Estado do Pará. Relatório técnico ${ }^{\circ}$ 003/2018, Belém: Coordenação de Qualidade/Instituto Evandro Chagas, 2018.

JUNK, W.J.; PIEDADE, M.T.F.; SCHÖNGART, J.; COHN-HAFT, M.; ADENEY J.M.; WITTMANN, F. A classification of major naturally-occurring 
Amazonian lowland wetlands. Wetlands, v. 31, n. 4, p. 623-640, 2011. https:// doi.org/10.1007/s13157-011-0190-7

JUNQUEIRA, M.; ALVES, K.; PAPROCKI, H.; CAMPOS, M.; CARVALHO, M.; MOTA, H.; ROLLA, M. Índices bióticos para avaliação de qualidade de água de rios tropicais - síntese do conhecimento e estudo de caso: Bacia do Alto Rio Doce. Revista Brasileira de Ciências Ambientais, n. 49, p. 15-33, 2018. https://doi.org/10.5327/Z2176-947820180322

KAWASHIMA, R.S.; GIANNOTTI, M.A.; ALMEIDA, C.M.; QUINTANILHA, J.A. Modelagem Dinâmica Espacial como ferramenta para simulação de cenários da paisagem na região portuária da Baixada Santista. Boletim de Ciências Geodésicas, v. 22, n. 4, p. 703-718, 2016. https://doi.org/10.1590/ s1982-21702016000400040

KIMMERER, W.J. Physical, biological, and management responses to variable freshwater flow into the San Francisco estuary. Estuaries, v. 25, p. 1275-1290, 2002. https://doi.org/10.1007/BF02692224

KRUMHANSL, K.A.; KRKOSEK, W.H.; GREENWOOD, M.; RAGUSH, C.; SCHMIDT, J.; GRANT, J.; BARRELL, J.; LU, L.; LAM, B.; GAGNON, G.A.; JAMIESON, R.C. Assessment of Arctic community wastewater impacts on marine benthic invertebrates. Environmental Science \& Technology, v. 49, n. 2, p. 760-766, 2015. https://doi.org/10.1021/es503330n

LECERF, A.; RICHARDSON, J.S. Biodiversity-ecosystem function research: insights gained from streams. River Research and Applications, v. 26, n. 1, p. 45-54, 2010. https://doi.org/10.1002/rra.1286

LIJTEROFF, R.; LIMA, L.; PRIERI, B. Uso de líquenes como bioindicadores de contaminación atmosférica en la ciudad de San Luis, Argentina. Revista Internacional de Contaminación Ambiental, v. 25, n. 2, p. 111-120, 2009.

LIMA, M.O.; ALVES, F.D.S.; CARNEIRO, B.S.; COSTA, V.D. Caracterização preliminar dos impactos ambientais, danos ao ecossistema e riscos a saúde decorrentes do lançamento no rio Murucupi de efluentes do processo de beneficiamento de bauxita, Barcarena-Pará. Ananindeua: Instituto Evandro Chagas, 2009.

LIMA, M.O.; MENDES, L.C.S.; QUEIROZ, T.K.L; COSTA, B.N.S.; SILVA, M.M.C.; FERREIRA, D.P.M.; JÚNIOR, N.T.V.; CARNEIRO, B.S.; MARQUES, L.C.A.; FAIAL, K.C.F. Avaliação preliminar dos impactos ambientais referente ao transbordo e lançamentos irregulares de efluentes de lama vermelha na cidade de Barcarena, estado do Pará. Relatório Técnico. Belém: Instituto Evandro Chagas, 2018.

MACKINTOSH, T.J.; DAVIS, J.A.; THOMPSON, R.M. The influence of urbanisation on macroinvertebrate biodiversity in constructed stormwater wetlands. Science of the Total Environment, v. 536, p. 527-537, 2015. https://doi. org/10.1016/j.scitotenv.2015.07.066

MCGEOCH, M.A.; RENSBURG, B.J.V.; BOTES, B. The verification and application of bioindicators: a case study of dung beetles in a savanna ecosystem. Journal of Applied Ecology, v. 39, n. 4, p. 661-672, 2002. https://doi. org/10.1046/j.1365-2664.2002.00743.x

MEHROTRA, S.; BARDHAN, R.; RAMAMRITHAM, K. Outdoor thermal performance of heterogeneous urban environment: An indicator-based approach for climate-sensitive planning. Science of the Total Environment, v. 669, p. 872-886, 2019. https://doi.org/10.1016/j.scitotenv.2019.03.152

MOLINERI, C.; TEJERINA, E.G.; TORREJÓN, S.E.; PERO, E.J.I.; HANKEL, G.E. Indicative value of different taxonomic levels of Chironomidae for assessing the water quality. Ecological Indicators, v. 108, 105703, 2019. https:// doi.org/10.1016/j.ecolind.2019.105703

MOREIRA, L.B.; SAES, R.V.S.T.; PERES, T.F.; TANIGUCHI, S.; BÍCEGO, M.C.; MARINS, R.V.; ABESSA, D.M.S.A. Toxicity of sediments and dredged material from a semi-arid coastal system to marine invertebrates. Ecotoxicology and Environmental Contamination, v. 14, n. 1, p. 79-89, 2019. https://doi. org/10.5132/eec.2019.01.10

MOSBAHI, N.; SERBAJI, M.M.; PEZY, J.; NEIFAR, L.; DAUVIN, J. Response of benthic macrofauna to multiple anthropogenic pressures in the shallow coastal zone south of Sfax (Tunisia, central Mediterranean Sea). Environmental Pollution, v. 253, p. 474-487, 2019. https://doi.org/10.1016/j.envpol.2019.06.080

PELLETIER, M.C.; GOLD, A.J.; HELTSHE, J.F.; BUFFUM, H.W. A method to identify estuarine macroinvertebrate pollution indicator species in the Virginian Biogeographic Province. Ecological Indicators, v. 10, n. 5, p. $1037-$ 1048, 2010. https://doi.org/10.1016/j.ecolind.2010.03.005

PINHEIRO, S.; LIMA, M.; CARNEIRO, B.; COSTA TAVARES, V.; CÂMARA, $\mathrm{V}$. Effects of a shipwreck on the zooplankton community in a port region of the Amazon. Environmental Science and Pollution Research, v. 26, p. 5738-5750, 2019. https://doi.org/10.1007/s11356-018-3999-2

PRESTES, Y.O.; SILVA, A.C.; ROLLNIC, M.; ROSÁRIO, R.P. The M2 and M4 Tides in the Pará River Estuary. Tropical Oceanography, v. 45, n. 1, p. 16793013, 2017. https://doi.org/10.5914/tropocean.v45i1.15198

QUEIROZ, T.; NAKA, K.; MENDES, L.; COSTA, B.; DE JESUS, I.; CÂMARA, V.; LIMA, M. Human Blood Lead Levels and the First Evidence of Environmental Exposure to Industrial Pollutants in the Amazon. International Journal of Environmental Research and Public Health, v. 16, n. 17, p. 3047, 2019. https://doi.org/10.3390/ijerph16173047

RODRIGUEZ, P.; MARTINEZ-MADRID, M.; ARRATE, J.A.; NAVARRO, E. Selective feeding by the aquatic oligochaete Tubifex tubifex (Tubificidae, Clitellata). Hydrobiologia, v. 463, p. 133-140, 2001. https://doi. org/10.1023/A:1013199507341

ROSA FILHO, J.S.; AVIZ, D. Macrobenthic communities of an Amazonian estuary (Guajará Bay, Brazil): temporal and spatial changes. Journal of Coastal Research, v. 65, suppl., p. 123-128, 2013. https://doi.org/10.2112/SI65-022.1

ROSA FILHO, J.S.; BUSMAN, D.V.; VIANA, A.P.; GREGÓRIO, A.M.; OLIVEIRA, D.M. Macrofauna bentônica de zonas entre-marés não vegetadas do estuário do rio Caeté, Bragança, Pará. Boletim do Museu Paraense Emílio Goeldi Ciências Naturais, v. 1, n. 3, p. 85-96, 2006.

ROSA FILHO, J.S.; PEREIRA, L.C.C.; AVIZ, D.; BRAGA, C.F.; MONTEIRO, M.; COSTA, R.A.M.; ASP, N.E.; BEASLEY, C.R. Benthic estuarine assemblages of the Brazilian north coast (Amazonia Ecoregion). In: LANA, P.C.; BERNARDINO, A.F. (eds.). Brazilian estuaries. Berlin: Springer, 2018. v. 1. 236 p. 42-60. https://doi.org/10.1007/978-3-319-77779-5_2

ROSÁRIO, R.P.; BORBA, T.A.C.; SANTOS, A.S.; ROLLNIC, M. Variability of Salinity in Pará River Estuary: 2D Analysis with Flexible Mesh Model. Journal of Coastal Research, v. 75, suppl. 1, p. 128-133, 2016. https://doi.org/10.2112/ SI75-026.1

ROSENBERG, D.M.; RESH, V.H. Freshwater biomonitoring and benthic macroinvertebrates. New York: Chapman \& Hall, 1993. 488 p.

SARKAR, S.K. Bioaccumulation of Trace Metals in Macrozoobenthos of Sundarban Wetland. In: SARKAR, S.K. Trace Metals in a Tropical Mangrove Wetland. Singapore: Springer, 2018. p. 125-144. https://doi.org/10.1007/978-98110-2793-2_5

SCHUCHARDT, B.J.; HAESLOOP, U.; SCHIRMER, M. The tidal freshwater reach of the Weser estuary: Riverine or estuarine? Netherland Journal of Aquatic Ecology, v. 27, p. 215-226, 1993. https://doi.org/10.1007/BF02334785

SENA, B.A.; COSTA, V.B.; NAKAYAMA, L.; ROCHA, R.M. Composition of Microphytoplankton of an Estuarine Amazon River, Pará, Brazil. Biota Amazônia, v. 5, n. 2, p. 1-9, 2015. http://dx.doi.org/10.18561/2179-5746/ biotaamazonia.v5n2p1-9 
SILVA, R.F.; ROSA FILHO, J.S.; SOUZA, S.R.; SOUZA FILHO, P.W. Spatial and temporal changes in the structure of soft-bottom benthic communities in an Amazon estuary (Caeté estuary, Brazil). Journal of Coastal Research, v. SI64, p. 440-444, 2011.

SILVEIRA, S.; ORTEGA, I.; DUMONT, L.F.C. Artisanal trawling impact over prey availability and diet of estuarine megabenthic organisms in southern Brazil. Estuarine, Coastal and Shelf Science, v. 237, 106682, 2020. https://doi. org/10.1016/j.ecss.2020.106682

SMETI, E.; SCHILLER, D.; KARAOUZAS, I.; LASCHOU, S.; VARDAKAS, L.; SABATER, S.; TORNÉS, E.; MONLLOR-ALCARAZ, L.S.; GUILLEMARGILES, N.; MARTINEZ, E.; BARCELÓ, D.; ALDA, M.L.; KALOGIANNI, E.; ELOSEGI, A.; SKOULIKIDIS, N. Multiple stressor effects on biodiversity and ecosystem functioning in a Mediterranean temporary river. Science of the Total Environment, v. 647, p. 1179-1187, 2019. https://doi.org/10.1016/j. scitotenv.2018.08.105

SUGUIO, K. Introdução à sedimentologia. São Paulo: EDUSP, 1973.

SWARTZ, L.K.; HOSSACK, B.R.; MUTHS, E.; NEWELL, R.L.; LOWE, W.H. Aquatic macroinvertebrate community responses to wetland mitigation in the Greater Yellowstone Ecosystem. Freshwater Biology, v. 64, n. 5, p. 942-953, 2019. https://doi.org/10.1111/fwb.13276

VAN RENSBURG, B.J.; MCGEOCH, M.A.; CHOWN, S.L.; VAN JAARSVELD, A.S. Conservation of heterogeneity among dung beetlesin the Maputaland
Centre of Endemism, South Africa. Biological Conservation, v. 88, n. 2, p. $145-$ 153, 1999. https://doi.org/10.1016/S0006-3207(98)00109-8

VELOSO, V.G.; NEVES, G.; CAPPER, L.A. Sensitivity of a cirolanid isopod to human pressure. Ecological Indicators, v. 11, n. 3, p. 782-788, 2011. https://doi. org/10.1016/j.ecolind.2010.10.004

VIANA, A.P.; FRÉDOU, F.L. Ichthyofauna as bioindicator of environmental quality in an industrial district in the amazon estuary, Brazil. Brazilian Journal of Biology, v. 74, n. 2, p. 315-324, 2014. https://doi.org/10.1590/15196984.16012

VIANA, A.P.; FRÉDOU, F.L.; FRÉDOU, T. Measuring the ecological integrity of an industrial district in the Amazon estuary, Brazil. Marine Pollution Bulletin, v. 64, n. 3, p. 489-499, 2012. https://doi.org/10.1016/j. marpolbul.2012.01.006

VIANA, A.P.; FRÉDOU, F.L.; MONTES, C.S.; ROCHA, R. Fish histopathology and catalase activity as biomarkers of the environmental quality of the industrial district on the Amazon estuary, Brazil. Acta Scientiarum, Biological Sciences, v. 35, n. 3, p. 395-401, 2013. https://doi.org/10.4025/actascibiolsci. v35i3.18032

YOSHIDA, C.E.; ROLLA, A.P.P.R. Atributos ecológicos da comunidade bentônica e índices de qualidade da água de ambientes urbanos, rurais e preservados. Acta Limnologica Brasiliensa, v. 24, n. 3, p. 235-243, 2012. https:// doi.org/10.1590/S2179-975X2012005000041 